
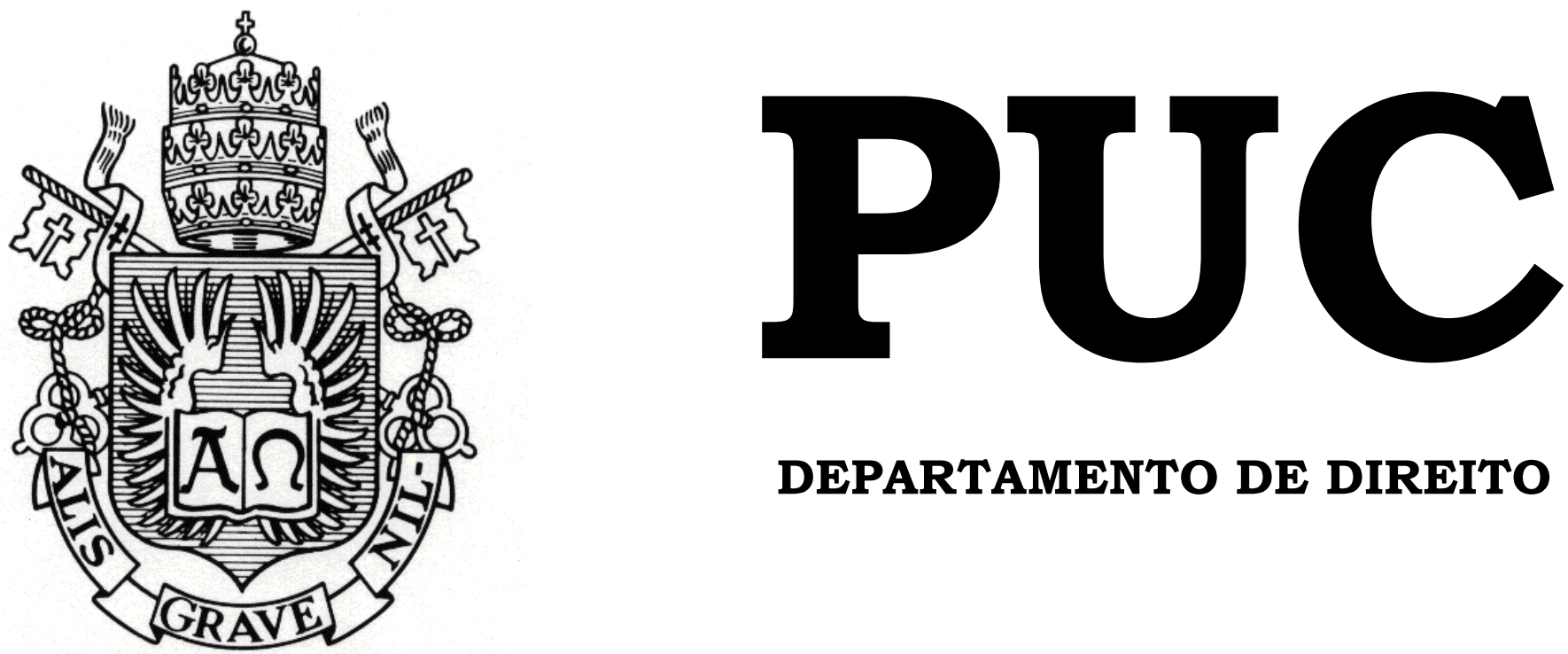

DEPARTAMENTO DE DIREITO

\title{
A INJÚRIA E O PROBLEMA DA OFENSA COMO CRIME
}

por

FLAVIA KAMENETZ NHUCH

ORIENTADOR: FÁBIO CARVALHO LEITE

2015.2

PONTIFÍCIA UNIVERSIDADE CATÓLICA DO RIO DE JANEIRO

RUA MARQUÊS DE SÃO VICENTE, 225 - CEP 22453-900

RIO DE JANEIRO - BRASIL 


\title{
INJÚRIA E O PROBLEMA DA OFENSA COMO CRIME
}

\author{
por
}

FLAVIA KAMENETZ NHUCH

Monografia apresentada ao Departamento de Direito da Pontificia Universidade Católica do Rio de Janeiro (PUC-Rio) para a obtenção do Título de Bacharel em Direito.

Orientador: Fábio Carvalho Leite 


\section{AGRADECIMENTOS}

Aos meus pais, Simone e Sergio, e irmãos, André e Sabrina.

Aos meus avós, Ana Lúcia, Dov, Eva e Maurício.

Ao meu padrasto, Arthur Lavigne, e à minha madrasta, Verônica Levin.

Às minhas amigas-mais-do-que-amigas, Rachel Glatt, Lívia Rocha, Luíza

Fernandes, Amanda Bergman, Anna Clara Marzocchi, Bianca Lemos, Ana

Luisa Martins e Júlia Drebtchinsky.

A todos os companheiros do escritório Arthur Lavigne Advogados Associados.

Aos meus amigos da Contra Corrente.

À minha mestre jedi, Roberta Maia Gomes.

Ao meu orientador, Fábio Carvalho Leite.

A eles, por tudo. 
"We don't see things as they are, we see things as we are." Samuel ben Nahman

"Everything we hear is an opinion, not a fact. Everything we see is a perspective, not the truth." Marcus Aurelius 


\section{RESUMO}

O presente trabalho tem como objetivo a análise do crime de injúria à luz da doutrina e da jurisprudência perante alguns dos princípios que regem o Direito Penal brasileiro. Posteriormente, pretendeu-se averiguar a configuração da injúria simples diante da contraposição entre a liberdade de expressão e o direito à honra. Para tanto, após problematizar-se o embate entre ambos os direitos, foi realizada uma pesquisa para examinar a estabilidade - ou a falta dela - na compreensão da tipificação do delito de injúria nos diversos casos apresentados. Por fim, além de ter sido realizada uma comparação entre os crimes contra a honra do Código Penal atual e do anteprojeto do novo Código Penal, foi feito um paralelo entre as normas que regulam tais delitos no Brasil e em alguns outros países que compõem a Organização dos Estados Americanos, e que optaram por sua descriminalização.

Palavras chave: Injúria; Crimes Contra a Honra; Honra; Liberdade de Expressão. 


\section{SUMÁRIO}

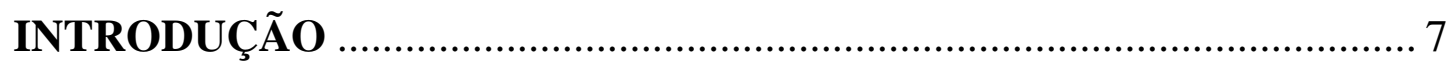

CAPÍTULO 1 - ASPECTOS GERAIS DO TIPO PENAL DA INJÚRIA 10

1.1. O crime de injúria segundo a doutrina brasileira.............................. 10

1.2. A importância do finalismo penal para a tipificação do delito de

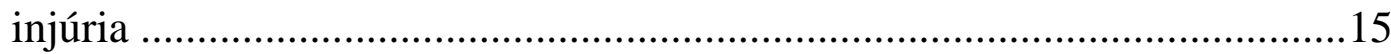

1.3. A injúria como crime formal e o Direito Penal como ultima ratio 19

CAPÍTULO 2 - O CRIME DE INJÚRIA E A LIBERDADE DE

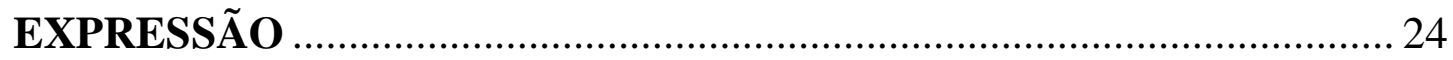

2.1. Fundamentos teóricos da liberdade de expressão.............................. 24

2.2. A tensão entre a honra e a liberdade de expressão no crime de injúria

2.3. Problemas do tipo penal da injúria …………................................... 30

CAPÍTULO 3 - A IDENTIFICAÇÃO DO CRIME DE INJÚRIA NA

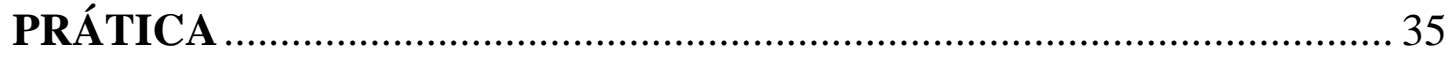

3.1. Tipificação do crime de injúria em diversos contextos .................... 35

3.2. Divergência jurisprudencial............................................................... 43

3.3. Doutrina versus a "vida como ela é" ..............................................5 50

CAPÍTULO 4 - A NORMATIZAÇÃO DOS CRIMES CONTRA A

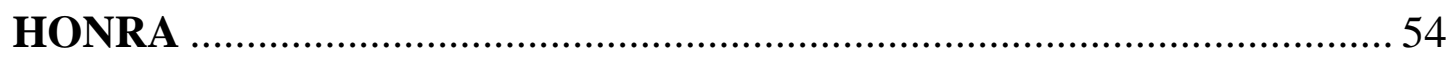

4.1. O Código Penal brasileiro atual e o anteprojeto do novo Código

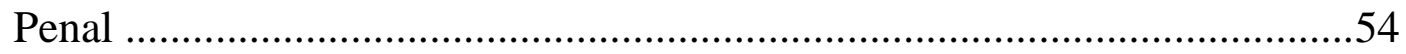

4.2. Os crimes contra a honra no âmbito da Organização dos Estados

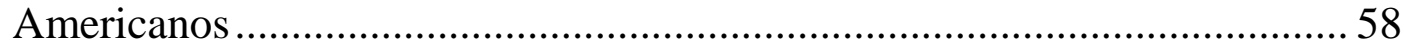

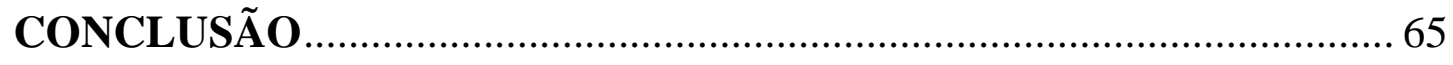

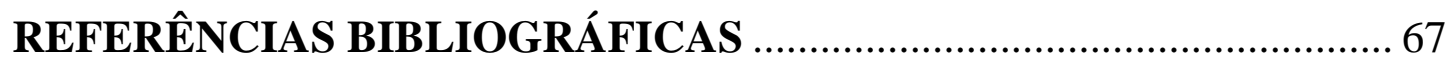




\section{INTRODUÇÃO}

Em junho de 2006, os estudantes da Faculdade de Artes, Ciências e Tecnologias (Facet), de Salvador, na Bahia, se reuniram algumas vezes para protestar contra o aumento da mensalidade e contra a mercantilização da educação. Levaram cartazes, faixas e apitos.

Marcell Moraes, presidente do Diretório Central dos Estudantes (DCE) e aluno do curso de administração da universidade, que havia sido suspenso por 15 dias por conta do último protesto que organizou, criticou Ceres Guedes, coordenadora do seu curso. Disse no microfone que ela era uma "péssima administradora" e "vergonha para a classe" durante a manifestação ${ }^{1}$.

Ceres processou Marcell por injúria e difamação, sendo ele condenado somente pela prática do primeiro crime pelo Juizado Especial Criminal de Itapuã em julho de $2007^{2}$. Em sede recursal, a Terceira Turma Recursal Cível e Criminal de Salvador manteve a sentença do juízo de piso, que o condenou a 80 dias de detenção - pena convertida ao pagamento de uma multa de 30 salários mínimos, que, na época, equivalia a $\mathrm{R} \$ 12.450,00$.

A colisão entre a liberdade de expressão e os direitos de personalidade, duas garantias fundamentais constitucionais, está claramente ilustrada no caso apresentado. Os crimes contra a honra ainda são penalizados com a privação da liberdade, como ocorreu no caso de Marcell Moraes, mesmo que posteriormente convertida em prestação pecuniária. Na verdade, não existe um debate acerca das implicações em cercear a liberdade de expressão no âmbito penal em prol do direito à honra.

\footnotetext{
${ }^{1}$ ARAGAKI, Bruno. Estudante paga $R \$ 12$ mil de multa por chamar professora de "péssima". Disponível em: <http://educacao.uol.com.br/ultnot/2008/07/03/ult105u6699.jhtm>; $<$ http://www.jcnet.com.br/editorias_noticias.php?codigo=129781\&ano=2008> Acessado em 05 de novembro de 2015; Aluno é condenado por criticar coordenadora. Disponível em: <http://extra.globo.com/noticias/brasil/aluno-condenado-por-criticar-coordenadora-505858.html > Acessado em 05 de novembro de 2015.

${ }^{2}$ Processo n ${ }^{\circ}$ 0078766-45.2006.805.0001 do $2^{\circ}$ Juizado Especial Criminal de Itapuã.
} 
A valoração da liberdade de expressão não se deve ao reconhecimento de sua importância apenas para os discursos elogiosos e positivos. A proteção a esse princípio é tanto o mais importante quando direcionada às falas consideradas abjetas, posto que nelas reside a verdadeira essência do que seja livre. A liberdade não é medida pelo que se considera adequado, mas pela sua incondicionalidade. É importante, também, não perder de vista que, fundamentais que são os direitos de personalidade, que açambarcam a honra, ditas prerrogativas vão sempre existir e estar presentes sem depender de atos formais de aquisição. São direitos inatos e indisponíveis, oponíveis ao Estado e aos particulares de uma sociedade.

Diante dessa certeza, inevitável é a incerteza quanto ao resultado do confronto entre o pleno exercício da liberdade de expressão e o direito à honra, mesmo diante de suas incondicionalidades.

O Código Penal brasileiro, redigido em 1940, mantém-se íntegro em sua forma original de tipificar como crime a injúria e as demais formas de violação aos direitos da personalidade. $\mathrm{O}$ direito à liberdade de expressão tornou-se reconhecido apenas 48 anos após a edição do Código Penal, sendo, sob a perspectiva temporal, uma prerrogativa muito mais recente, além de nascida depois de mais de 20 anos de um governo ditatorial, no qual a expressão era submetida a uma censura prévia e arbitrária. Desta forma, os critérios de valoração de ambos os direitos ainda sofrem distorções que fragilizam a prevalência do direito à liberdade de expressão quando em confronto com o direito à honra.

Tendo presente os esclarecimentos acima narrados, é objetivo deste trabalho analisar as repercussões da criminalização da opinião quando em confronto com o direito à honra e o seu desalinhamento com o princípio de ultima ratio que deve ser observado para a aplicação do Direito Penal.

Para tanto, são apresentados, no Capítulo 1, os aspectos gerais do tipo penal da injúria, incluindo a necessidade de se averiguar a existência ou não da 
intenção do autor do fato em ofender, o que configuraria o animus injuriandi, elementar para caracterizar o crime de injúria. Este Capítulo problematiza, ainda, o uso do Direito Penal, nos casos de criminalização da injúria, em não conformação com o princípio da ultima ratio.

No Capítulo 2, são explorados os aspectos de tensão entre a liberdade de expressão e o direito à honra, levando em consideração a subjetividade e a necessidade de contextualização da ofensa proferida para que, assim, esta possa ser caracterizada como crime de injúria.

O Capítulo 3 traz a questão estudada para a vida prática, apresentando uma pesquisa pela qual evidencia-se a dificuldade em estabelecer, de forma definitiva, a ocorrência do crime de injúria, por conta da abstração do entendimento individual do fato gerador deste ilícito. Dita abstração é demonstrada através da colação de casos jurisprudenciais, cujas decisões proferidas por diferentes tribunais apresentam resultados contraditórios e paradoxais. Ao final deste Capítulo, apresenta-se a incompatibilidade da doutrina, que alicerça a criminalização do delito de injúria, com a vida real, na qual diversas variantes podem desconstituir o animus injuriandi, fundamental para a tipificação do crime.

Por fim, no Capitulo 4, são analisadas as disposições normativas dos crimes contra a honra no Código Penal vigente, contrapondo-se ditas normas com aquelas propostas para o novo Código Penal. Adicionalmente, é realizada uma comparação entre a questão da penalização dos referidos delitos em alguns países membros da Organização dos Estados Americanos, para auxiliar na contextualização do paradigma brasileiro atual. 


\section{CAPÍTULO 1 - ASPECTOS GERAIS DO TIPO PENAL DA INJÚRIA}

O crime de injúria contempla características e peculiaridades estabelecidas pela doutrina penal brasileira que serão apresentadas neste capítulo, mediante uma explicação detalhada de tais atributos. Será, ainda, exibida a contraposição da existência deste delito diante das bases do Direito Penal em nosso Estado de Intervenção Mínima.

\subsection{O crime de injúria segundo a doutrina brasileira}

Em meio às condutas delituosas pertencentes ao capítulo que versa sobre os crimes contra a honra do Código Penal brasileiro de 1940, encontra-se o crime de injúria (artigo 140), considerado o delito menos grave desse tipo de infração penal.

De acordo com a doutrina penal brasileira, a conduta aqui abordada é tipificada ao se ofender, de maneira voluntária, a dignidade ou o decoro da vítima, isto é, sua honra subjetiva (conceito que o indivíduo tem de si mesmo $)^{3}$.

$\mathrm{O}$ artigo supramencionado prevê que:

\footnotetext{
"Injuriar alguém, ofendendo-lhe a dignidade ou o decoro:

Pena - detenção, de um a seis meses, ou multa.

$\S 1^{\mathrm{o}}-\mathrm{O}$ juiz pode deixar de aplicar a pena:

I - quando o ofendido, de forma reprovável, provocou diretamente a injúria;
}

\footnotetext{
3 "A conduta típica consiste em injuriar alguém, ofendendo-lhe a dignidade ou o decoro". PRADO, Luiz Regis. Curso de direito penal brasileiro, volume 2: parte especial, arts. 121 a 249. 7a ed. rev. e ampl. São Paulo: Editora Revista dos Tribunais, 2008. Pág. 249.

"Injuriar é ofender a dignidade ou o decoro de alguém. A injúria, que é a expressão da opinião ou conceito do sujeito ativo, traduz sempre desprezo ou menoscabo pelo injuriado. É essencialmente uma manifestação de desprezo e de desrespeito suficientemente idônea para ofender a honra da vítima no seu aspecto interno." BITENCOURT, Cezar Roberto. Tratado de direito penal, 2: parte especial, dos crimes contra a pessoa. $11^{\text {a }}$ ed. São Paulo: Saraiva, 2011. Pág. 348.
} 
II - no caso de retorsão imediata, que consista em outra injúria.

$\S 2^{\circ}$ - Se a injúria consiste em violência ou vias de fato, que, por sua natureza ou pelo meio empregado, se considerem aviltantes:

Pena - detenção, de três meses a um ano, e multa, além da pena correspondente à violência.

$\S 3^{\circ}$ - Se a injúria consiste na utilização de elementos referentes a raça, cor, etnia, religião, origem ou a condição de pessoa idosa ou portadora de deficiência:

Pena - reclusão de um a três anos e multa."4

Assim sendo, é importante dissecar o tipo penal para avaliar os mais diversos aspectos da injúria, como, por exemplo, os sujeitos ativo e passivo, tipos objetivo e subjetivo, bem jurídico tutelado, o instituto do perdão judicial, previsto no parágrafo $1^{\circ}$ do artigo, a injúria real, prevista no parágrafo $2^{\circ}$, e a injúria preconceituosa, prevista no parágrafo $3^{\circ}$.

Em relação ao primeiro ponto, o sujeito ativo, ou seja, o autor do fato, pode ser qualquer pessoa - por isso a injúria é classificada como um delito comum $^{5}$. O sujeito passivo (a vítima), no entanto, de acordo com a maioria da doutrina e jurisprudência ${ }^{6}$, é tão somente a pessoa física, pois entende-se que a pessoa jurídica não possui honra subjetiva a ser tutelada pelo tipo penal, mas apenas honra objetiva. A ofensa proferida à pessoa jurídica, então, seria direcionada aos seus dirigentes. Os menores de tenra idade, por esse ângulo, não podem ser vítimas do crime, já que não têm consciência de dignidade ou decoro. O mesmo ocorre com os doentes mentais, mas somente na hipótese em que esses não tenham a capacidade de compreender a ofensa.

Já o tipo objetivo da injúria consiste em injuriar alguém, insultando sua dignidade, que diz respeito aos seus atributos sociais e morais, ou decoro, referente ao sentimento da vítima em relação a seus atributos físicos e

\footnotetext{
${ }^{4}$ Artigo 140 do Código Penal.

${ }^{5}$ DELMANTO, Celso [et al.]. Código penal comentado. 8a ed. rev., atual. e ampl. São Paulo: Saraiva, 2010. Pág. 512.

${ }^{6}$ PRADO, Luiz Regis. Comentários ao Código Penal: doutrina, jurisprudência selecionada, conexões lógicas com os vários ramos do direito. 3a ed. reform., atual. e ampl. São Paulo: Editora Revista dos Tribunais, 2006. Pág. 470; JESUS, Damásio E. de. Código Penal anotado. 18a ed. atual. São Paulo: Saraiva, 2007. Pág. 497; ACrim 496.677, JTACrimSP 97:143, RT 652:259 e RJTJSP 126:564.
} 
intelectuais. O crime, conhecido por ter uma forma livre, pode ser perpetrado por diversos meios, quais sejam, palavras, escritos, imagens, gestos etc.

O tipo subjetivo, por sua vez, é baseado no dolo, direto ou eventual, de ofender alguém. Dessa forma, há a necessidade da intenção do autor do fato em injuriar a vítima de maneira livre e consciente, conhecida como animus injuriandi, para a caracterização do crime. Caso contrário, a conduta será atípica. $^{7}$

Curiosa, no entanto, é a consumação do crime. Essa ocorre quando a injúria chega ao conhecimento da vítima, ainda que ela não se sinta realmente ofendida ${ }^{8}$. O crime, portanto, é formal, sendo necessária somente a adequação típica ao ilícito penal, e o resultado não precisa de fato ocorrer para que a conduta se tipifique, bastando o ânimo em injuriar.

A injúria se diferencia da difamação e da calúnia no sentido em que na primeira se atribui uma qualidade negativa a uma pessoa, na segunda se imputa um fato negativo com a finalidade macular a reputação da vítima e, por fim, na terceira há a imputação falsa de um fato definido como crime praticado por outrem.

O bem jurídico tutelado pela injúria é a honra subjetiva, que, conforme previamente esclarecido, é o sentimento que cada um tem quanto a seus atributos $^{9}$. Como a honra é um bem jurídico disponível, o consentimento do ofendido exclui a ilicitude da conduta.

\footnotetext{
${ }^{7}$ DELMANTO, Celso [et al.]. Código penal comentado. 8a ed. rev., atual. e ampl. São Paulo: Saraiva, 2010. Pág. 512.

${ }^{8}$ TJMG, ACrim 133.955, $2^{\text {a }}$ Câmara, rel. Des. Herculano Rodrigues. RT 766:686

${ }^{9}$ Outra classificação possível quanto a honra é a de ela ser objetiva, conforme explica E. Magalhães Noronha: "conceito ou apreço que a pessoa goza na vida comunitária". Noronha traz, também, outra categorização de injúria, podendo ela ser absoluta ou relativa: "Autores há que dividem a injúria em absoluta ou relativa. A primeira existe quando a expressão tem por si mesma e para qualquer um significado ofensivo constante e unívoco, como certas palavras ou gestos, criados exatamente para manifestar desprezo, escárnio etc. É relativa quando a expressão que a concretiza assume caráter ofensivo, se proferida em determinadas circunstâncias ou condições de forma, tom, modo, lugar, tempo, pessoa etc." NORONHA, E. Magalhães. Direito penal. São Paulo: Saraiva,1988-1991. Págs. $124 / 125$
} 
O parágrafo $1^{\circ}$ do artigo 140 do Código Penal prevê a figura do perdão judicial, que ocorre quando o juiz deixa de aplicar a pena nos casos de provocação e retorsão imediata. Na primeira hipótese, diante da provocação direta e reprovável da vítima do crime de injúria, o autor do fato lhe dirige a ofensa. A conduta do provocador não consiste em um crime e, por conseguinte, não se assemelha à injúria - caso contrário, seria retorsão imediata. No segundo caso, como indicado, o ofendido rebate a injúria do autor do fato com outra injúria, devendo essa resposta ser imediata.

$\mathrm{O}$ perdão judicial, de acordo com a maioria da doutrina ${ }^{10}$, é uma faculdade atribuída ao juiz, que determinará, de acordo com o caso em concreto, se deverá aplicá-lo ou não. Como resultado do deslinde do instituto do perdão judicial, o Superior Tribunal de Justiça formulou o enunciado de súmula $\mathrm{n}^{\circ} 18$, estabelecendo que "a sentença concessiva do perdão judicial é declaratória da extinção da punibilidade, não subsistindo qualquer efeito condenatório". No entanto, há quem entenda que a sentença que concede o perdão é condenatória, somente livrando o condenado dos efeitos principais da condenação $^{11}$.

O parágrafo $2^{\circ}$ do artigo trata da hipótese da injúria real, que é uma modalidade qualificada do tipo penal. Versa sobre a situação em que há violência ou vias de fato praticadas, seja por lesão corporal $^{12}$ ou comportamento agressivo, respectivamente. É preciso que o agente atue com o animus injuriandi, pois, caso contrário, subsistirá somente o crime de lesão

\footnotetext{
10 Argumento contra: "Embora as opiniões dominantes concebam o perdão judicial como mero benefício ou favor do juiz, entendemos que se trata de um direito público subjetivo de liberdade do indivíduo, a partir do momento em que preenche os requisitos legais." BITENCOURT, Cezar Roberto. Tratado de direito penal, 2: parte especial, dos crimes contra a pessoa. $11^{a}$ ed. São Paulo: Saraiva, 2011. Pág. 352.

11 JESUS, Damásio E. de. Código Penal anotado. 18a ed. atual. São Paulo: Saraiva, 2007. Pág. 501.

12 Discorda: "É possível empregar violência, isto é, força física, gestos abruptos, exercendo-os injuriosamente, isto é, desrespeitosamente, sem, contudo, tipificar lesões corporais." BITENCOURT, Cezar Roberto. Tratado de direito penal, 2: parte especial, dos crimes contra a pessoa. 11a ed. São Paulo: Saraiva, 2011. Pág. 359.
} 
corporal (artigo 129 do Código Penal) ou a contravenção de vias de fato (artigo 21 do Decreto 3.688/41).

Por fim, o parágrafo $3^{\circ}$ tipifica a injúria preconceituosa ou discriminatória. $\mathrm{O}$ autor do fato nesse caso tem a intenção de ofender o decoro ou a dignidade de alguém através de sua raça, cor, etnia, religião, origem, condição de pessoa idosa ou de portadora de deficiência ${ }^{13}$. Essa modalidade, também qualificada, tem uma pena cominada maior do que a do caput e do parágrafo $2^{\circ}$ por conta do seu elevado grau de reprovabilidade (mais alto do que o das outras duas modalidades). Para a ocorrência dessa espécie de injúria, deverá haver um elemento especial do tipo que seria o de discriminar a vítima em razão das condições previamente mencionadas.

Existe, ainda, uma forte crítica doutrinária em relação ao parágrafo $3^{\circ}$ do artigo 140, do Código Penal, por conta dos princípios da proporcionalidade e da razoabilidade, já que se assinala como exemplo que a pena prevista para o crime de homicídio culposo (artigo 121, parágrafo $3^{\circ}$, do Código Penal) é de detenção, também de um a três anos. Denota-se, assim, a clara desproporção referente à punição entre o crime de injúria preconceituosa e o de homicídio culposo, haja vista que o primeiro tipo penal tutela tão somente a honra, enquanto o segundo tutela a vida e, assustadoramente, ambos têm a mesma pena cominada em seus respectivos artigos.

Uma distinção considerável a se fazer é entre a injúria preconceituosa e o racismo. A primeira ocorre quando o autor do fato ofende a honra subjetiva de alguém através de palavras depreciativas, dirigindo-as somente à pessoa da vítima, enquanto o racismo sobrevém quando alguém se refere à raça de forma objetiva e geral.

Enfim, é importante, também, fazer menção à outros aspectos penais que interferem processualmente no delito de injúria.

\footnotetext{
${ }^{13}$ MIRABETE, Julio Frabbini e FABBRINI, Renato N. Manual de Direito Penal - Parte especial: arts. 121 a 234-B do CP. Volume II. 28a ed. rev. e atual. até 4 de janeiro de 2011. São Paulo: Atlas, 2011. Pág. 133.
} 
As disposições comuns aos crimes contra a honra, previstas no artigo 141 do Código Penal, trazem a possibilidade de aumento de pena em um terço quando o crime de injúria é cometido contra o Presidente da República ou contra chefe de governo estrangeiro, contra funcionário público, em razão de suas funções ou na presença de várias pessoas, ou, ainda, por meio que facilite sua divulgação. O parágrafo $1^{\circ}$ do artigo prevê a hipótese de aplicação da pena em dobro caso o crime seja cometido mediante pagamento ou promessa de recompensa. ${ }^{14}$

O artigo 142 do Código Penal traz o cenário da exclusão do crime, existente no momento em que a ofensa é proferida em juízo na discussão da causa, quando for em forma de crítica literária, artística ou científica, ou se for uma opinião desfavorável, emitida por funcionário público em razão de seu serviço. $\mathrm{O}$ ofendido pode, ainda, pedir explicações em juízo quanto à injúria perpetrada e, se o autor do fato se recusar a dá-las, ou o juiz não as considerar satisfatórias, o acusado responderá pela ofensa, à luz do artigo 144 do Código Penal.

Feita a presente análise, será explorado adiante o aspecto essencial para a configuração desse tipo penal: a intenção em cometer o crime de injúria.

\subsection{A importância do finalismo penal para a tipificação do delito de injúria}

Conforme previamente mencionado, o artigo 140 do Código Penal, ao tratar do crime de injúria, somente prevê a modalidade dolosa do tipo penal. O autor do fato precisa, então, ter a intenção de injuriar alguém, ofendendo-lhe a

\footnotetext{
${ }^{14}$ BITENCOURT, Cezar Roberto. Tratado de direito penal, 2: parte especial, dos crimes contra a pessoa. $11^{\mathrm{a}}$ ed. São Paulo: Saraiva, 2011. Pág. 366.
} 
dignidade ou o decoro ${ }^{15}$. Caso não haja o animus injuriandi, como não é prevista a possibilidade do crime culposo, a conduta se torna atípica.

Entender o ânimo e a vontade do sujeito que pratica o crime de injúria é essencial para constatar se este de fato ocorreu e, por isso, essa análise é imprescindível no presente estudo, já que a injúria é configurada somente perante uma conduta dolosa.

É possível imaginar, antes de mais nada, o desafio que o processo penal enfrenta ao tentar desvendar a existência da intenção - ou a falta dela - do acusado em casos controvertidos, para buscar uma solução no conflito. Somase, ainda, a pressão da perspectiva já pacificada de que o Direito Penal funciona como um ramo subsidiário aos demais, devendo somente ser invocado em ultima ratio, em função do desgaste e do constrangimento que o acusado no processo penal vivencia.

Isso posto, faz-se necessária a análise da relação entre o finalismo penal e o crime aqui abordado.

A metodologia analítica criminal utilizada pelo direito penal brasileiro nos dias de hoje, pelo menos pela maioria da jurisprudência e doutrina formadora de opinião, é realizada a partir da teoria finalista. Essa teoria, que se contrapõe às diretrizes do causalismo ${ }^{16}$, desenvolvida graças à contribuição dos alemães Hans Welzel, Werner Niese, Armin Kaufmann, Günter Stratenwerth e Hans Joachim Hirsch e do espanhol José Cerezo Mir, tem como elemento essencial o valor do ser humano e é sustentada pelo entendimento de que o homem, como ser individual e independente, raciocina, realiza escolhas e age

\footnotetext{
15 "É sutil a diferença entre uma e outro: dignidade é o sentimento da nossa própria honorabilidade ou valor moral; decoro é o sentimento, a consciência de nossa respeitabilidade pessoal" HUNGRIA, Nelson. Comentários ao Código Pena, volume VI. 5a ed. Rio de Janeiro: Forense, 1980. Pág. 91.

16 “(...) a ação se definiria como comportamento humano voluntário, que produz modificação no mundo exterior (conceito naturalístico de ação), compreendendo um processo interno de vontade; a atuação dessa vontade no mundo exterior; por meio de um fazer ou de um não fazer, e o resultado dessa ação. (...) o conteúdo da vontade não pertence à ação, e, sim, à culpabilidade. Para determinar o conceito de ação basta saber que o comportamento foi voluntário, não importando nem o conteúdo nem o alcance da vontade (...).” FRAGOSO, Heleno Cláudio. Lições de direito penal: parte geral. 16a ed. Rio de Janeiro: Forense, 2003. Pág. 184.
} 
de maneira livre, devendo ser responsabilizado por suas condutas. Assim, a atividade praticada voluntariamente pelo indivíduo é voltada para um fim, havendo um motivo pelo qual o agente praticou o delito.

Sendo assim, para melhor exemplificar no que consiste tal teoria, é imperativo introduzir alguns conceitos teóricos e básicos do Direito Penal.

Uma conduta criminosa pode ser conceituada analiticamente como um fato típico, antijurídico e culpável. Significa, por isso, que não há crime sem que: (i) o fato constitua uma ação ou omissão; (ii) a ação ou omissão corresponda a um tipo penal previamente previsto; (iii) o fato seja contrário ao direito; e (iv) o comportamento seja juridicamente culpável e, portanto, reprovável.

Então, a ação do agente, entre as demais partes que compõem a noção de crime, acaba, no contexto de tal teoria, por comportar o elemento subjetivo do dolo e da culpa, diferentemente da teoria causalista, na qual o dolo e culpa se encontram na parte da culpabilidade. Sendo assim, pode-se definir a conduta do crime como uma ação ou omissão humana voluntária regida pelo dolo ou pela culpa (e, no caso da injúria, regida somente pelo dolo, como previamente elucidado).

O caminho que o crime percorre até atingir sua finalidade, comumente conhecido como iter criminis, pode ser dividido em quatro fases ${ }^{17}$. A primeira delas é a do planejamento, que é uma etapa intelectual no desenvolvimento da conduta do crime e que, por conta do princípio da lesividade, é penalmente irrelevante, já que nela surge tão somente o dolo e não a concretização da conduta. A segunda etapa é a preparação, na qual o agente pratica uma série de atos que, apesar de não caracterizarem a prática do crime, têm este como seu objetivo. A terceira etapa é a execução, momento no qual o agente pratica efetivamente a conduta do delito. A quarta fase, por fim, ocorre na

\footnotetext{
${ }^{17}$ Para alguns autores, há também uma quinta fase do iter criminis, que seria a do exaurimento. O exaurimento do crime ocorre ao mesmo tempo da consumação nos crimes materiais e os de mera conduta e posterior a consumação nos crimes formais, virando seus desdobramentos.
} 
consumação, o que, em crimes formais ou de mera conduta, é a simples prática do crime, enquanto em crimes materiais é a ocorrência do resultado naturalístico ${ }^{18}$.

Dessa forma, a conduta dolosa executada, seja na modalidade consumada $^{19}$ ou na tentada ${ }^{20}$, é o resultado da soma entre o que o agente quer (elemento intelectual), a decisão dele em realizá-la (elemento volitivo) e sua devida execução, objetivando alcançar um resultado final no momento desta.

Conforme leciona Cerezo Mir:

“(...) a adoção do critério valorativo da concepção do homem como um ser responsável destaca como essencial para a valoração jurídica, a estrutura final da ação humana. Se o Direito vincula as consequências jurídicas a uma ação, deverá respeitar sua estrutura lógico-objetiva. A valoração jurídica há de recair então, necessariamente, sobre uma unidade final-causal da ação."21

Diante dessa acepção, o esclarecimento da ocorrência do animus injuriandi ao longo do iter criminis é essencial para a configuração do crime da injúria, pois, inexistindo esse elemento, a conduta perpetrada torna-se atípica diante das lentes do finalismo e, portanto, não haverá sanção pelo Direito Penal brasileiro atual.

Cabe citar, também, as hipóteses defendidas pela maioria da doutrina penal em que, curiosamente, não ocorre o crime de injúria por motivos especiais pré-determinados, como, por exemplo, as situações nas quais expressões são proferidas no calor do momento ${ }^{22}$, já que entende-se que inexiste o dolo, elemento essencial para a configuração do tipo penal da injúria, como previamente elucidado.

\footnotetext{
${ }^{18}$ BITENCOURT, Cezar Roberto. Tratado de direito penal: parte geral, I. 17a ed. rev., ampl. e atual. de acordo com a Lei n. 12.550, de 2011. São Paulo: Saraiva, 2012. Pág. 522.

19 Art. 14, I, CP: "Diz-se o crime consumado, quando nele se reúnem todos os elementos de sua definição legal."

${ }^{20}$ Art. 14, II, CP: "Diz-se o crime tentado, quando, iniciada a execução, não se consuma por circunstâncias alheias à vontade do agente."

${ }^{21}$ PRADO, Luiz Regis. Curso de direito penal brasileiro, volume 1: parte geral, arts. $1^{\circ}$ a $120.3^{\mathrm{a}}$ ed. rev., atual. e ampl. São Paulo: Editora Revista dos Tribunais, 2002. Pág, 82.

${ }^{22}$ RT 491:307, 525:391, 544:353.
} 
Nesse mesmo sentido, há também, a título exemplificativo, as figuras do animus criticandi, animus defendendi, animus jocandi, animus corrigendi, ${ }^{23}$ entre outros, que preveem, respectivamente, o ânimo de criticar de maneira sincera, com o objetivo de ajudar o criticado; defender um direito que leva ao cometimento da injúria, não havendo, nesse caso, ilicitude; brincar sem o intuito de ofender; e corrigir, que é o que ocorre, por exemplo, na relação entre pais e filhos, caracterizando um exercício regular de direito.

Como se depreende da concepção acima, é possível identificar certa insegurança jurídica diante da existência de casos similares julgados de formas diferentes, em razão da dificuldade em se estabelecer a ocorrência ou não do animus injuriandi.

Como corolário, é facilmente percebido o obstáculo que o Direito Penal atual enfrenta se estabelecido que ele é sustentado por um viés humanitário e de abrangência preferencialmente mínima (ultima ratio), estando obrigado a esmiuçar cada caso em concreto no que tange ao delito da injúria para verificar a vontade em injuriar nas mais diversas conjunções e contextos.

\subsection{A injúria como crime formal e o Direito Penal como ultima ratio}

O Direito Penal exerce o papel de solucionador de conflitos através do amparo e tutela de bens jurídicos previamente determinados em lei, constituídos de certo valor para a sociedade, como, por exemplo, a vida, o patrimônio, a liberdade, a honra e diversos outros. Para que haja harmonia e equilíbrio nas relações interpessoais individuais e da sociedade em geral, a maneira encontrada para punir o violador de regras e desestabilizador da paz social seria através de penas e medidas de segurança.

\footnotetext{
${ }^{23}$ JESUS, Damásio E. de. Código Penal anotado. 18a ed. atual. São Paulo: Saraiva, 2007. Págs. 487, 488 e 500 .
} 
Esse ramo do ordenamento jurídico se sustenta sobre os pilares de quatro características: o preventivo geral, o preventivo especial, o retributivo e o ressocializador ${ }^{24}$. O primeiro deles se funda na demonstração, para os demais indivíduos da sociedade, das consequências impostas a quem quebra as regras, como uma tentativa de criar o medo de ser punido no corpo social, prevenindo, assim, o cometimento de outros ilícitos. O segundo caráter é voltado para a pessoa específica que cometeu o delito, de maneira a puni-la para que ela não volte a delinquir. O caráter retributivo, por sua vez, existe na medida em que é imposto um mal ao indivíduo infrator, por conta de sua conduta contrária ao ordenamento jurídico. Por fim, a atribuição ressocializadora da seara penal visa a ensinar ao autor do fato ilícito a convivência pacífica na coletividade, para que ele não perturbe novamente a paz social.

Tal Direito se diferencia dos demais por conta do peso e da gravidade do enfrentamento de um processo penal, e das possíveis punições englobadas por ele. Devido a tais particularidades, esse ramo é norteado por diversos princípios. No entanto, para os fins desse estudo, trataremos apenas de dois: o da intervenção mínima e o da fragmentariedade.

O princípio da intervenção mínima ${ }^{25}$, também conhecido como princípio da subsidiariedade, determina que a lei penal será aplicada nos casos em que for absolutamente imprescindível para defender o bem jurídico violado, vez que seria ineficaz protegê-lo com o auxílio de outro ramo do Direito. Assim, o Direito Penal deve ser aplicado em ultima ratio, ou seja, em última razão (instância).

Já o princípio da fragmentariedade ${ }^{26}$, resultado da intervenção mínima, conduz um limite à aplicação totalitária da lei penal, demonstrando que a

\footnotetext{
${ }^{24}$ FRAGOSO, Heleno Cláudio. Lições de direito penal: parte geral. 16a ed. Rio de Janeiro: Forense, 2003. Pág. 343.

${ }^{25}$ BITENCOURT, Cezar Roberto. Tratado de direito penal: parte geral, I. 17a ed. rev., ampl. e atual. de acordo com a Lei n. 12.550, de 2011. São Paulo: Saraiva, 2012. Pág. 51.

${ }^{26}$ BITENCOURT, Cezar Roberto. Tratado de direito penal: parte geral, I. 17a ed. rev., ampl. e atual. de acordo com a Lei n. 12.550, de 2011. São Paulo: Saraiva, 2012. Pág. 53.
} 
incidência desta não é absoluta. É necessária, portanto, a observância do caso em concreto para considerar se a ação ou omissão praticada merece, de fato, ser coibida diante da violação intolerável de um bem jurídico.

No que tange à questão abordada no presente trabalho, pode-se traçar uma relação curiosa entre os princípios fundamentais supramencionados que regem o Direito Penal brasileiro e a normatização e compreensão doutrinária e jurisprudencial acerca do crime de injúria, no sentido de que o ramo penal do ordenamento jurídico preza por sua aplicação em última instância, mas, ao mesmo tempo, cria um tipo penal que incrimina a mera ação de injuriar, sem a necessidade de haver resultado, em prol da honra da suposta vítima. É, no mínimo, contraditório.

Ora, o delito de injúria prevê a pena de um a seis meses na hipótese do caput e de três meses a um ano no parágrafo $2^{\circ}{ }^{27}$. É um crime de menor potencial ofensivo, ou seja, tem menor relevância quando comparado aos demais julgados em varas criminais comuns, e, assim, tem como órgão jurisdicional competente o Juizado Especial Criminal.

Contudo, mesmo diante de tais circunstâncias, a injúria é considerada um crime formal, ou seja, a mera adequação típica da conduta praticada resulta, instantaneamente, no cometimento do ilícito, a partir do momento em que chega ao conhecimento da vítima a injúria perpetrada. Não há, assim, necessidade da ocorrência do resultado, que é, no caso, a efetiva ofensa à dignidade ou ao decoro de alguém, maculando sua honra.

Se o Direito Penal é subsidiário aos demais ramos, por estes não serem capazes de resolver conflitos em certas situações da forma eficaz como a seara penal o faz, surge a latente dúvida de que, talvez, as circunstâncias que envolvem o tipo penal da injúria não sejam necessárias e de ultima ratio.

\footnotetext{
${ }^{27} \mathrm{O}$ parágrafo $1^{\circ}$ do art. $140, \mathrm{CP}$, trata do perdão judicial, enquanto o parágrafo $3^{\circ}$, que prevê a injúria preconceituosa, tem a pena prevista de um a três anos, devendo, portanto, ser julgado perante a vara criminal comum.
} 
Além disso, as características previamente ressaltadas ${ }^{28}$ da esfera penal não se justificam e nem se mostram necessárias para coibir o crime de injúria, pois elas têm como objetivo a não repetição do crime, seja pelo autor do fato, seja pelo resto da sociedade, a imposição de uma punição e o ensinamento ao autor do fato a conviver pacificamente com os demais cidadãos. Como o delito de injúria é, de fato, subjetivo, a tutela do Direito Penal em conflitos supostamente injuriosos poderia ter como consequência o esfriamento do debate (chilling effect) e a ausência de pluralidade de ideias e informações, diante de seu caráter repressivo e retributivo, bem como o medo que as pessoas possam ter de sofrer sanções penais.

A realidade atual, então, sob as lentes de um viés pragmático, é a seguinte: o suposto autor do fato emite uma opinião ou pensamento que desagrada a suposta vítima. Percebe-se a colisão entre o direito à liberdade de expressão e o direito à honra e, em nossa conjuntura penal, a honra é tutelada em desfavor da liberdade de expressão. $\mathrm{O}$ autor do fato tem, portanto, um direito negado a si, que seria o de se manifestar livremente, e, por conta da criminalização dos crimes de opinião, ainda tem que enfrentar uma ação penal, podendo vir a sofrer constrangimentos e penas, mesmo se ele não tiver efetivamente maculado a honra da vítima, já que a injúria é um crime formal.

A forma com a qual o Direito Penal enfrenta a questão dos crimes de opinião é completamente incompatível com os princípios que o sustentam, já que, além de criminalizar uma matéria de menor potencial ofensivo sem ao menos haver necessidade de violação ao bem jurídico tutelado, é visível que o tipo penal da injúria poderia ser facilmente tratado e solucionado por outros ramos do ordenamento jurídico. Um bom exemplo seria pelo Direito Civil, através da utilização do direito de resposta ou de previsões coercitivas para o autor do fato, como obrigações de não fazer ou reparações por indenização indenizações estas não muito diferentes da realidade, uma vez que é

\footnotetext{
${ }^{28}$ Preventivo geral, preventivo especial, retributivo e ressocializador.
} 
extremamente comum a privação de liberdade ser convertida em prestação pecuniária no que tange à punição do crime de injúria.

Nesse sentido, Anderson Schreiber discorre que "a manutenção desses tipos penais na atualidade é bastante discutível. Para muitos penalistas, as violações à honra poderiam ser solucionadas exclusivamente por meio da responsabilidade civil, sem necessidade de se criminalizar essas condutas." ${ }^{29}$

Como conclusão, conforme apontado, não há necessidade da tutela do Direito Penal para lidar com o que conhecemos como o crime de injúria, já que a utilização dessa área do direito não seria efetivamente de ultima ratio.

${ }^{29}$ SCHREIBER, Anderson. Direitos da personalidade. 2. ed. São Paulo: Atlas, 2013. Pág. 72. 


\section{CAPÍTULO 2 - O CRIME DE INJÚRIA E A LIBERDADE DE EXPRESSÃO}

Feitas as considerações iniciais do crime de injúria, trataremos somente do crime previsto no caput do artigo 140 do Código Penal, a chamada injúria simples, para os fins do presente trabalho. Será abordado, assim, o embasamento conceitual da liberdade de expressão, posicionado de maneira fronteiriça à honra, bem jurídico tutelado pela injúria.

Com a tensão entre o direito à honra e à liberdade de expressão, por fim, serão apontadas algumas questões quanto à estrutura normativa e elementos essenciais ao tipo penal da injúria mediante a judicialização de conflitos de opinião.

\subsection{Fundamentos teóricos da liberdade de expressão}

Prevista nos incisos IV e IX do artigo $5^{\circ}$ da Constituição da República de 1988, a liberdade de expressão consagra um divisor de águas entre a Carta Magna atual e a anterior - que remetia a uma era de flagrante censura e cerceamento de liberdades em geral -, quando declara que "é livre a manifestação do pensamento, sendo vedado o anonimato", e que "é livre a expressão da atividade intelectual, artística, científica e de comunicação, independentemente de censura ou licença".

Calcada em valores iluministas, tal liberdade também é garantida pela Declaração dos Direitos do Homem e do Cidadão em seus artigos 10 e $11^{30}$,

\footnotetext{
${ }^{30}$ Art. $10^{\circ}$. Ninguém pode ser molestado por suas opiniões, incluindo opiniões religiosas, desde que sua manifestação não perturbe a ordem pública estabelecida pela lei.

Art. $11^{\circ}$. A livre comunicação das idéias e das opiniões é um dos mais preciosos direitos do homem. Todo cidadão pode, portanto, falar, escrever, imprimir livremente, respondendo, todavia, pelos abusos desta liberdade nos termos previstos na lei.
} 
bem como no artigo 13 do Pacto San José da Costa Rica ${ }^{31}$, entre outros tratados internacionais.

O direito de se expressar é caracterizado pela exteriorização de crença, opinião, pensamento, concepções de mundo, conhecimento, juízo de valor, entre outros. As liberdades de comunicação, religiosa, de expressão intelectual, artística e científica, de expressão cultural e, por fim, de transmissão e recepção do conhecimento decorrem de forma primária da liberdade de opinião.

A liberdade de expressão, que é a que trataremos de maneira abrangente para os fins do presente trabalho, é de suma importância para qualquer regime que se considere minimamente democrático ${ }^{32}$, vez que este depende da existência de um debate plural para que se analise a vontade coletiva, emergida através do confronto de ideias entre as mais diversas camadas da sociedade e da possibilidade de os cidadãos obterem informações. ${ }^{33}$ Por isso, com ela, os indivíduos de uma sociedade podem escolher ou não em receber, utilizar e reproduzir certas informações - eles decidem por si próprios.

\footnotetext{
${ }^{31}$ Artigo 13 - Liberdade de pensamento e de expressão

1. Toda pessoa tem o direito à liberdade de pensamento e de expressão. Esse direito inclui a liberdade de procurar, receber e difundir informações e idéias de qualquer natureza, sem considerações de fronteiras, verbalmente ou por escrito, ou em forma impressa ou artística, ou por qualquer meio de sua escolha.

2. O exercício do direito previsto no inciso precedente não pode estar sujeito à censura prévia, mas a responsabilidades ulteriores, que devem ser expressamente previstas em lei e que se façam necessárias para assegurar: a) o respeito dos direitos e da reputação das demais pessoas; b) a proteção da segurança nacional, da ordem pública, ou da saúde ou da moral públicas.

3. Não se pode restringir o direito de expressão por vias e meios indiretos, tais como o abuso de controles oficiais ou particulares de papel de imprensa, de frequências radioelétricas ou de equipamentos e aparelhos usados na difusão de informação, nem por quaisquer outros meios destinados a obstar a comunicação e a circulação de idéias e opiniões.

4. A lei pode submeter os espetáculos públicos a censura prévia, com o objetivo exclusivo de regular o acesso a eles, para proteção moral da infância e da adolescência, sem prejuízo do disposto no inciso 2.

5. A lei deve proibir toda propaganda a favor da guerra, bem como toda apologia ao ódio nacional, racial ou religioso que constitua incitamento à discriminação, à hostilidade, ao crime ou à violência.

32 "Liberdade para dizer e escrever o que se quer é uma necessidade inescapável da democracia." LEWIS, Antony. Liberdade para as ideias que odiamos: uma biografia da Primeira Emenda à Constituição americana. São Paulo: Aracati, 2011. Pág. 13.

${ }^{33}$ SARMENTO, Daniel. Livres e iguais: estudos de Direito Constitucional. Rio de Janeiro: Editora Lumen Juris, 2006. Pág. 281.
} 
Para que a liberdade de expressão possa existir, portanto, há uma pretensão de que o Estado não a censure ${ }^{34}$; caso contrário, o possível confronto de ideias é inibido, surgindo o chamado "chilling effect" (efeito de esfriamento de debates), diante do receio de coerções através da seara penal.

O debate público não pode, ou pelo menos não deveria, ser submetido ao controle do $\operatorname{Estado}^{35}$. Essa é uma hipótese temerária, já que ele pode determinar como lhe convém o que deve ou não ser difundido na sociedade, para filtrar informações que lhe sejam desfavoráveis, assim como o contrário. ${ }^{36}$ Essa liberdade foi inserida na Constituição da República para proteger as pessoas que fazem manifestações que incomodam, que desagradam - ela é importante justamente em tais situações.

A garantia de se manifestar não precisa necessariamente ser constituída pela expressão propriamente dita: abrange, também, o direito ao silêncio e o de não se informar. Depreende-se que o titular da garantia, então, não é obrigado a exercê-la, ${ }^{37}$ já que, como o indivíduo molda seu próprio pensamento, ele tem a faculdade de exteriorizá-lo ou não.

A dúvida que emerge consubstancia-se, por exemplo, na hipótese em que um indivíduo se expressa de uma determinada maneira e posteriormente é condenado por isso, seja civil ou criminalmente: ele poderia ter, de fato, se manifestado? Por que ter uma norma constitucional conferindo a liberdade de manifestação, se o discurso permitido é tão somente o elogioso, que não necessita de tutela e garantia?

\footnotetext{
${ }^{34}$ MENDES, Gilmar Ferreira. Curso de direito constitucional. 2a ed. rev. e atual. São Paulo: Saraiva, 2008. Pág. 360.

35 "O bom funcionamento da democracia liga-se, portanto, à existência de um debate público dinâmico e plural, que não esteja submetido ao controle nem do Estado, nem do poder econômico ou político privado." SARMENTO, Daniel. Livres e iguais: estudos de Direito Constitucional. Rio de Janeiro: Editora Lumen Juris, 2006. Pág. 282.

${ }^{36}$ De acordo com Ronald Dworkin, "o Estado insulta seus cidadãos e nega a eles a sua responsabilidade moral, quando decreta que não se pode confiar neles para ouvir opiniões que possam persuadi-los a adotar convicções perigosas ou ofensivas". Freedom's Law: The Moral Reading of the American Constitution. Cambridge: Harvard University Press, 1966. Pág. 200.

${ }^{37}$ MENDES, Gilmar Ferreira. Curso de direito constitucional. 2a . ed. rev. e atual. São Paulo: Saraiva, 2008. Pág. 361.
} 
$\mathrm{Na}$ teoria, a explicação e adequação da garantia fundamental da liberdade de expressão é irretocável. Na prática, no entanto, constata-se dificuldades quando essa liberdade se confronta com outra garantia constitucional.

\subsection{A tensão entre a honra e a liberdade de expressão no crime de injúria}

A honra constitui um aspecto importante e notório nas relações entre os indivíduos na sociedade e, assim, a ordem jurídica urge em reconhecê-la e normatizá-la.

$\mathrm{O}$ direito fundamental à honra, consagrado pela Constituição da República em seu artigo $5^{\circ}$, inciso $\mathrm{X}$, emana do princípio da dignidade da pessoa humana e é conferida na esfera individual do ser humano quanto a sua integridade moral.

É, também, prevista no artigo 11 do Pacto San José da Costa Rica, que declara que "toda pessoa tem direito ao respeito da sua honra e ao reconhecimento de sua dignidade", assim como no artigo 12 da Declaração Universal dos Direitos Humanos ${ }^{38}$.

$\mathrm{O}$ direito à honra "refere-se à reputação pessoal e à consideração no meio em que se vive" ${ }^{39}$, e, de acordo com Antonio dos Reis Júnior, "a honra significa 'tanto o valor moral íntimo do homem, como a consideração social, o

\footnotetext{
${ }^{38} \mathrm{O}$ artigo 12 da Declaração Universal de Direitos Humanos prevê que "ninguém será sujeito a interferências na sua vida privada, na sua família, no seu lar ou na sua correspondência, nem a ataques a sua honra e reputação. Todo o homem tem direito à proteção da lei contra tais interferências ou ataques."

39 TEPEDINO, Gustavo; MORAES, Barboza, Heloisa Helena; MORAES, Maria Celina Bodin de. Código Civil interpretado conforme a Constituição da República. Rio de Janeiro: Renovar, 2004. Pág. 53.
} 
bom nome ou a boa fama, como, enfim, o sentimento, ou consciência, da própria dignidade pessoal'.",40

Seu amparo é de suma importância por envolver uma das partes mais íntimas do indivíduo, já que atinge seu sentimento e psique. É, assim, oponível tanto ao Estado quanto aos particulares da sociedade.

A doutrina faz, inclusive, uma distinção necessária entre a honra objetiva e a honra subjetiva ${ }^{41}$, considerando que a primeira diz respeito à reputação que a coletividade idealiza de alguém, enquanto a segunda seria o juízo que a pessoa faz de si mesma e seu sentimento quanto a seu decoro e dignidade.

No Direito Penal, a honra objetiva é o bem lesado nos crimes de calúnia e difamação e a subjetiva no crime de injúria. A doutrina penalista cita Nelson Hungria para complementar a questão ao dizer que a lei penal, por proteger a honra individual, defende o esforço do indivíduo em adquirir boa reputação, assim como tenta reprimir eventuais conflitos na sociedade ${ }^{42}$.

No entanto, conceituar os parâmetros e definições do direito à honra não é uma tarefa tão difícil quando comparado à ponderação de prevalência de direitos tão sagrados quanto estes em momentos de colisão em casos limítrofes, como, por exemplo, no caso do direito à honra e à liberdade de

\footnotetext{
${ }^{40}$ JÚNIOR, Antonio dos Reis. Novas perspectivas sobre o direito à honra: estudos sob a ótica civilconstitucional. Civilistica.com, a. 2. n. 3. p. 1 - 30. 2013. Disponível em: <http://civilistica.com/wpcontent/uploads/2015/02/Reis-J\%C3\%BAnior-civilistica.com-a.2.n.3.2013.pdf > Acessado em: 26 de outubro de 2015.

${ }^{41}$ A honra subjetiva "tem termômetro próprio inerente a cada indivíduo. É o decoro, é o sentimento de auto-estima, de avaliação própria que possuem valoração individual, não se podendo negar esta dor de acordo com sentimentos alheios." STJ, Terceira Turma, Recurso Especial 270.730 de relatoria da Ministra Nancy Andrighi, com julgamento em 19/12/2000.

42 "Protegendo a honra individual, a lei penal defende, além do interesse dos indivíduos uti singuli o interesse social, pois não só se propor evitar cizânias e vinditas no seio da convivência civil, como também visa a impedir que se frustre o justo empenho do indivíduo em merecer boa reputação pela sua conduta orientada no zelo de deveres sociamente úteis" HUNGRIA, Nelson. Comentários ao Código Pena, volume VI. $5^{\text {a }}$ ed. Rio de Janeiro: Forense, 1980. Pág. 41.

Bento de Faria também entende nesse sentido: "Todo indivíduo tem o direito de não ser ofendido, e, assim, protegendo-o, a lei visa não somente resguardar o seu interesse pessoal como, também, o interesse público da vida coletiva, evitando a sua perturbação pelas inimizades, ressentimentos, ódios ou vinganças". FARIA, Bento de. Código Penal brasileiro. Volume IV. 3a ed. atual. Rio de Janeiro: Distribuidora Record Editora, 1961. Pág. 168
} 
expressão - conflito em foco no presente trabalho diante do crime de injúria. Afinal, os cidadãos têm direito de se expressarem e, ao mesmo tempo, de terem sua honra preservada.

Essa é uma questão atual, debatida em tribunais de diversos países, vez que envolve a preservação de direitos da personalidade e da liberdade de expressão, elementos necessários em qualquer Estado que se considere democrático.

Por um lado, ao abrigar o direito à honra em detrimento da liberdade de expressão, compreende-se que a manifestação de pensamento não pode ser de todo absoluta, a ponto de ofender a garantia da honra (afinal, a ofensa é pessoal e, portanto, subjetiva) - já que se considera que o abuso da liberdade de expressão se dá pelo exercício fora dos limites para o qual o direito é garantido e tutelado diante de sua finalidade.

Por outro, se a prevalência da liberdade de expressão é defendida em prejuízo do direito à honra, afere-se que o discurso se encontra protegido diante da norma constitucional, independentemente de ser uma manifestação que, por ventura, ofende, por esta ser concebida como um valor vital para qualquer democracia e corolário para a dignidade humana. Reprimir o discurso do indivíduo seria reprimi-lo em sua essência.

Nossa Constituição prevê, no parágrafo primeiro do artigo 220, a limitação da liberdade de expressão quando houver possibilidade de violação dos direitos da personalidade, incluído o direito à honra.

Contudo, elevar o direito à honra a tal patamar, admitindo que ele funcione como limitador da liberdade de manifestação pode torná-lo perigoso, pois, contrario sensu, a honra seria transformada em um direito absoluto ${ }^{43}$ e, como se trata de uma questão subjetiva, variará conforme o que cada indivíduo atribui a si mesmo, podendo instaurar insegurança jurídica quanto a matéria.

\footnotetext{
${ }^{43}$ Leite, Fábio Carvalho. Liberdade de Expressão e Direito à Honra: novas diretrizes para um novo problema. In CLEVE, Clemerson Merlin, Freire Alexandre (Org.). Direitos Fundamentais e Jurisdição Constitucional. São Paulo: Ed. Revista dos Tribunais, 2014 (no prelo).
} 
A atuação dos tribunais torna casuística a situação dos direitos supramencionados, visto que, às vezes, criam desfechos distintos para casos similares, o que será demonstrado no tópico seguinte.

\subsection{Problemas do tipo penal da injúria}

No Brasil, a atuação do Direito Penal diante da violação do direito à honra e a consequente privação de liberdade - ainda que posteriormente convertida em prestação pecuniária ou de serviços à sociedade - serve como meio de coerção funcional para reprimir o crime de injúria.

No caso em apreço, é axiomático que tanto a liberdade de expressão quanto o direito à honra, como exposto no tópico anterior, são imprescindíveis para uma sociedade democrática, ficando evidente em diversos casos qual direito deve prevalecer acima do outro.

O desafio da colisão entre os dois direitos, no entanto, está calcado em casos concretos fronteiriços, nos quais ambos podem ser justificados à luz de dispositivos que possuem o mesmo peso normativo, causando dúvida sobre qual direito deverá se sobrepor ao outro.

Entre as mais diversas normas que tutelam a honra, sejam constitucionais, civis, penais, entre outras, o que está em foco no presente trabalho é a ofensa dirigida à pessoa de maneira que se atinja sua dignidade ou decoro coibida pela seara penal, como prevê o delito de injúria.

A ofensa, elemento essencial para a subsistência de tal tipo penal, carrega consigo um caráter subjetivo, vez que ela é pessoal - afinal, somente o ofendido é quem a sente. Por isso, por vezes o autor do fato, ou seja, a pessoa que proferiu a suposta ofensa, sequer sabe que cometeu algo ilícito, pelo simples fato de, por exemplo, acreditar com toda sua boa-fé e convicção que 
sua manifestação de pensamento não seria considerada ofensiva, ou, então, que ele tinha o direito de se expressar ${ }^{44}$.

Ante a abstração do que é efetivamente considerado como ofensa, é possível traçar uma comparação interessante entre a subjetividade da injúria e o teste de Rorschach $^{45}$ para auxiliar a ilustrar um possível problema da tipificação desse crime.

Tal teste, também conhecido como o "teste do borrão de tinta", é uma técnica psicológica de avaliação, na qual são exibidas manchas de tinta simétricas e é requerido ao paciente avaliado que diga quais figuras consegue extrair dessas manchas. Por óbvio, é de se imaginar o enorme leque de possibilidades do que é ou não identificado pelas manchas do teste entre os indivíduos avaliados. Alguns veem uma determinada imagem, enquanto outros extraem outra, e assim por diante.

Por conseguinte, considerando que para o tipo penal da injúria se configurar é necessário o dolo em ofender (animus injuriandi), perceptível à vítima de que a ela foi proferida uma ofensa, pode-se dizer que a subsistência do crime contra a honra aqui tratado é extremamente frágil. Isso ocorre porque há grande subjetividade e variedade no que pode ser ou não ser considerado injúria, dependendo do que o indivíduo vitimado considere como uma ofensa e, mais do que isso, do que ele interpreta como intenção do autor do fato em ofender - assim como os pacientes avaliados pelo teste de Rorschach

\footnotetext{
44 "Si la función del derecho penal o de su consecuencia más directa, la imposición de la pena de prisión sería, en los términos de la prevencíon general positiva, la afirmación por parte de la sociedad acerca de que una determinada norma tiene sentido, lo es porque protege ciertos bienes comúnmente aceptados por la sociedad como valiosos. En este caso, el bien 'jurídico' tutelado, el honor, es de difícil explicación, lo qual genera una directa consecuencia en la interpretación de las 'acciones' que el legislador ha querido incluir dentro de las palavras 'desacreditar' o 'desonrar'." BERTONI, Eduardo Andrés. Libertad de Expresión en el Estado de Derecho. Buenos Aires: Del Puerto, 2007, 2a edição. Pág. 38

45 "No contexto de justificação, o direito é visto como um teste de Rorschach, sempre sendo possíveis várias leituras diferentes das formulações normativas. É justamente porque tudo pode ser justificado juridicamente, que o contexto de justificação se torna supérfluo e desinteressante." STRUCHINER, Noel. Para falar de regras: o positivismo conceitual como cenário para uma investigação filosófica acerca dos casos difíceis do direito. Rio de Janeiro. 2005. Pág. 46. Tese (Doutorado em Filosofia) Departamento de Filosofia da PUC-Rio.
} 
identificam e captam imagens diferentes diante das mesmas manchas apresentadas.

Além da falta de taxação normativa, jurisprudencial ou doutrinária do que é ou não considerado ofensa e, assim, crime, também por causa da necessidade de aferição da existência de dolo, ainda há a dificuldade em determinar quais discursos são protegidos pela garantia constitucional da liberdade de expressão e a qual momento ela se estende.

Se existem "excludentes" de configuração do delito de injúria, como, por exemplo, através da crítica sincera (animus criticandi), da defesa de um direito (animus defendendi), da correção (animus corrigendi) e da brincadeira (animus jocandi), o grande desafio do Direito Penal frente a tamanha subjetividade e fragilidade dessa norma é na identificação da intenção em ofender, uma vez que não há dispositivos ou entendimentos consolidados no que constitui uma ofensa ou qual discurso está efetivamente protegido.

O Direito Penal, por conta de sua gravidade e pelo fato de ser subsidiário aos demais ramos do Direito, não poderia - ou pelo menos não deveria - lidar com dispositivos flexíveis e subjetivos que dependem da interpretação da ofensividade de um discurso e da verificação de animus, como no caso da injúria, um crime de menor potencial ofensivo ${ }^{46}$.

Por isso, diante da intangibilidade do que é considerado como um discurso ofensivo $^{47}$ ou até onde vai a liberdade de expressão, é possível encontrar casos concretos similares com decisões diferentes, o que demonstra clara insegurança jurídica no crime aqui analisado.

\footnotetext{
46 "Não se olvide que o imbróglio é limítrofe entre a ofensa e a crítica. Não se debate que o querelado é, em seus textos, agressivo, deselegante e até mal-educado. Porém é seu estilo. E estando o caso numa zona cinzenta entre, como se disse, o desacato e a opinião desfavorável, a própria dúvida instalada revela o desate que se deve dar, de acordo com o conhecidíssimo brocardo in dubio pro reo." Voto do Juiz Relator José Wellington Bezerra da Costa Neto na apelação n 0024348-59.2011.8.26.0564 da Segunda Turma Recursal Criminal do Colégio Recursal de Santo André.

47 "Resulta al menos problemático determinar a priori si una acción determinada lesionará o no el honor subjetivo de un determinado indivíduo. Por ejemplo, decirle asesino implacable a un mercenario puede que no lesione en lo más mínimo su honor subjetivo; la misma expresión a un policía puede generar todo lo contrario." BERTONI, Eduardo Andrés. Libertad de Expresión en el Estado de Derecho. Buenos Aires: Del Puerto, 2007, 2a edição. Pág. 47
} 
Além disso, outro elemento que corrobora para a subsistência de conclusões diferentes em situações parecidas é a ausência do stare decisis ${ }^{48}$ na jurisprudência brasileira, pois os precedentes criados não são efetivamente empregados pelos tribunais.

A doutrina penal, apesar de apresentar didaticamente os conceitos e embasamentos da injúria, não relaciona tal crime contra a honra com a garantia da liberdade de expressão. Mesmo reconhecendo a importância da honra e da liberdade de opinar, carece de explicação doutrinária quanto a tal conflito, que é polêmico e efetivamente atual.

Dessa forma, por conta da subjetividade e fragilidade do crime de injúria, da inexistência de jurisprudência pacífica sobre a determinação do que é ofensa e do fato de que argumentos contrários com mesmo peso hierárquico podem defender tanto a liberdade de expressão quanto o direito à honra, a escolha de qual direito deve prevalecer diante de conflitos de opinião e, principalmente, no caso da injúria, é penosa e árdua.

O que se pretende evitar é justamente o declarado pelo Ministro Marco Aurélio, quando disse:

"Idealizo para o caso concreto a solução mais justa e posteriormente vou ao arcabouço normativo, vou à dogmática buscar o apoio. E como a interpretação é acima de tudo um ato de vontade, na maioria das vezes, encontro o indispensável apoio." 49

\footnotetext{
48 "De regra, o termo stare decisis significa tanto a vinculação, por meio do precedente, em ordem vertical (ou seja, como representação da necessidade de uma Corte inferior respeitar decisão pretéria de Corte superior), como horizontal (a Corte respeitar decisão anterior proferida no seu interior, ainda que a constituição dos juízes seja alterada). Essa é a posição adotada, entre outros, por Neil Duxbury e Mevil Aron Eisenberg. Em outra senda, há aqueles que optam por distinguir o termo stare decisis de precedent, como Frederick Schauer, para quem, 'tecnicamente, a obrigação de uma corte de seguir decisões prévias da mesma corte é dita como sendo stare decisis (...), e o termo mais abrangente precedente é usado para se referir tanto à stare decisis, quanto à obrigação de uma corte inferior de seguir decisões de uma superior'." MARINONI, Luiz Guilherme. Aproximação crítica entre as jurisdições de civil law e de common law e a necessidade de respeito aos precedentes no Brasil. Revista da Faculdade de Direito - UFPR, Curitiba, n. 49, p. 11-58, 2009.

${ }^{49}$ Marco Aurélio vê sua homenagem como "estímulo". Disponível em: $\langle$ http://www.conjur.com.br/2010-jul-06/idealizo-solucao-justa-depois-vou-ar-normas-marco-aurelio $\rangle$.
} Acessado em: 01 de outubro de 2015. 
O testemunho do Ministro do Supremo Tribunal Federal carrega consigo a demonstração de um inevitável "decisionismo" por parte dos tribunais brasileiros, que tem como consequência o surgimento da insegurança jurídica. Assim, casos concretos parecidos são eventualmente julgados de formas diferentes. 


\section{CAPÍTULO 3 - A IDENTIFICAÇÃO DO CRIME DE INJÚRIA NA PRÁTICA}

Diante dos possíveis problemas agregados ao crime de injúria, no presente capítulo será apresentada e analisada uma pesquisa realizada pela autora juntamente com os professores Fábio Leite e Ivar H. Rodriguez, que teve como objetivo observar a tipificação da injúria nas mais diversas situações. Posteriormente, será acrescentada jurisprudência acerca do tema que, em suas decisões, aborda as questões controvertidas suscitadas. Por fim, será explorada a compatibilidade entre o que a doutrina prega em seus exemplos de injúria e como tais situações ocorreriam na vida real.

\subsection{Tipificação do crime de injúria em diversos contextos}

Em outubro de 2015, foi realizada uma pesquisa anônima com 100 (cem) profissionais do direito ${ }^{50}$, entre eles advogados, juízes, desembargadores, promotores e defensores públicos, para que se pudesse analisar a compreensão acerca da existência ou não do crime de injúria nas diversas situações apresentadas.

Os eventos expostos na pesquisa retratavam 6 (seis) casos verídicos de injúria, quais sejam, de Merval Pereira vs. Paulo Henrique Amorim, de Edmundo Alves de Souza Neto vs. Revista Veja ${ }^{51}$, de Ricardo Teixeira vs. Juca Kfouri, de Roberto Requião vs. Ricardo Boechat, de Paulo Henrique Amorim vs. Diogo Mainardi e, por fim, de Edson Ulisses de Melo vs. Cristian Góes.

No entanto, para que os entrevistados não reconhecessem os casos reais e decidissem pela tipificação ou não da injúria de acordo com os resultados

\footnotetext{
${ }^{50}$ Leite, Fábio Carvalho; Nhuch, Flavia Kamenetz; Rodriguez, Ivar H. Liberdade de expressão e o crime de injúria (artigo ainda a ser publicado).

Enquanto 14 pessoas foram entrevistadas através de um questionário físico, 86 pessoas responderam ao questionário no site Qualtrics, de Harvard.

${ }^{51}$ Especificamente, seu diretor de redação à época dos fatos, Tales Alvarenga.
} 
efetivos previamente conhecidos ou por questão de afinidade, os nomes das vítimas, autores do fato, revistas, jornais e qualquer outra informação que pudesse identificar os personagens foram alterados, enquanto a situação fática permaneceu idêntica.

O primeiro caso apresentado, então, com os nomes modificados, versa sobre os fatos de quando Paulo Henrique Amorim, jornalista, apresentador do programa Domingo Espetacular na Rede Record e detentor do blog Conversa Fiada, chamou Merval Pereira, jornalista d'O Globo, de "jornalista bandido" em uma matéria de seu blog intitulada de "CPI da Veja. Dias a Merval: valetudo não vale nada". ${ }^{52}$ Tal narração tinha como núcleo uma notícia do jornalista Mauricio Dias, da revista Carta Capital, na qual discorria sobre a relação da revista Veja com o bicheiro Carlinhos Cachoeira.

Paulo Henrique Amorim foi condenado pelo Juizado Especial Criminal de São Paulo a 1 mês e 10 dias de detenção pelo crime de injúria - pena esta convertida por uma restritiva de direitos ${ }^{53}$. Em sede recursal, o Supremo Tribunal Federal manteve sua condenação, pois o Ministro Relator Celso de Mello entendeu que

"a jurisprudência da Corte tem reconhecido que o direito à livre manifestação do pensamento não se reveste de caráter absoluto nem ilimitado, expondo-se por isso mesmo às restrições que emergem do próprio texto da Constituição Federal, destacando-se a intangibilidade do patrimônio moral de terceiros." ${ }^{54}$

Quando indagado aos 100 entrevistados se Paulo Henrique havia cometido o crime de injúria ou não, 66 declararam que sim, enquanto 34

\footnotetext{
${ }^{52}$ AMORIM, Paulo Henrique. CPI da Veja. Dias a Merval: vale-tudo não vale nada. Disponível em: $\langle$ http://www.conversaafiada.com.br/pig/2012/05/07/cpi-da-veja-dias-a-merval-vale-tudo-nao-valenada> Acessado em 11 de outubro de 2015.

${ }_{53}$ Paulo Henrique Amorim é condenado por injúria. Disponível em: 〈http://www.conjur.com.br/2014abr-28/paulo-henrique-amorim-condenado-injuria-merval-pereira>. Acessado em 11 de outubro de 2015.

${ }^{54}$ STF mantém condenação de Paulo Henrique Amorim por injúria contra Merval Pereira. Disponível em: $\quad<$ http://www.migalhas.com.br/Quentes/17,MI226911,101048-

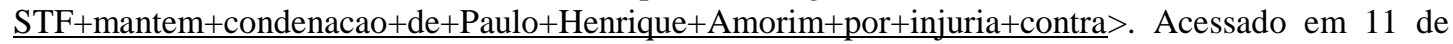
outubro de 2015.
} 
acreditam que não houve a tipificação do delito. Dos 66 que inferiram que havia ocorrido o crime de injúria, 34 pessoas trabalham na área criminal.

A segunda situação do questionário tratava do evento em que o diretor de redação Tales Alvarenga da revista Veja foi acusado de ter perpetrado o crime de injúria por causa de uma matéria da referida revista com o título "Animais no volante? Casos como o do jogador Edmundo mostram o que a Justiça pode fazer contra a barbárie do trânsito". A notícia tratava de um acidente de automóvel causado pelo jogador de futebol Edmundo, que resultou na morte de três pessoas ${ }^{55}$.

Tales foi absolvido tanto pela $1^{\text {a }}$ Câmara do Tribunal de Alçada Criminal de São Paulo, que decidiu por 2 a $1 \mathrm{em}$ seu favor, quanto pelo Superior Tribunal de Justiça em matéria civil ${ }^{56}$.

Entre as 100 pessoas entrevistadas no presente questionário, 6 entenderam que Tales Alvarenga cometeu o delito de injúria, enquanto 94 discordaram. Das 6 pessoas que analisaram a existência do crime, 66,7\% trabalha na seara penal.

No terceiro caso apresentado, que demonstrava o conflito entre o jornalista Juca Kfouri e o ex-presidente da Confederação Brasileira de Futebol Ricardo Teixeira, o primeiro havia feito uma reportagem publicada na revista

\footnotetext{
55 PINHO, Débora. Edmundo vs. Veja. Disponível em: 〈http://observatoriodaimprensa.com.br/primeiras-edicoes/dbora-pinho-2/>. Acessado em 15 de setembro de 2015.

${ }^{56}$ Veja se livra de pagar indenização a Edmundo. Disponível em: <http://www.conjur.com.br/2009jun-23/veja-livra-pagar-indenizacao-edmundo-chama-lo-animal>. Acessado em 15 de setembro de 2015. No acórdão do Recurso Especial n ${ }^{\circ}$ 1.021.688/RJ de relatoria do Ministro Sidnei Beneti, à época da data do julgamento, inferiu que "a imagem exposta já havia resultado, evidentemente, em positivas vantagens, inclusive patrimoniais, no decorrer da carreira do atleta, com a contra-partida, contudo, da abertura de caminho para a negativa exposição, dado o caráter polissêmico da expressão. Logo, no caso, não se tem acréscimo negativo à matéria, mas, sim, a simples transposição de qualificação já antes criada, consentida e usufruída, posta à receptividade e ao debate da opinião pública", declarada pela justiça penal a não caracterização dos crimes considerados contra a honra, inexistirá o ilícito civil correspondente, salvo se a absolvição decorrer de insuficiência de provas" e " não houve, no caso, dano causado ao autor, mas tecnicamente, simples incômodo ou desconforto pela exposição do lado negativo da figura pública. Portanto, não há o que indenizar ao autor".
} 
Caros Amigos na qual chamava o segundo de "subchefe da máfia do futebol nacional" em matéria que tratava do futebol brasileiro ${ }^{57}$.

O Ministro Relator Celso de Mello do Supremo Tribunal Federal entendeu que "os jornalistas têm o direito de criticar, mesmo de forma contundente, qualquer pessoa ou autoridade" e, portanto, não havia se configurado o animus injuriandi ou qualquer "prática ilícita contra a honra subjetiva do suposto ofendido". ${ }^{58}$ Assim, o recurso que visava à condenação de Juca Kfouri foi improvido.

$\mathrm{Na}$ ocasião em que foi questionado aos 100 entrevistados se eles vislumbravam a configuração da injúria no caso em apreço, 51 pessoas entenderam não subsistir tal crime, enquanto 49 inferiram que Juca havia injuriado Ricardo - e, dessas 49, 28 pessoas trabalham na área criminal.

O quarto caso apresentado foi o de quando Ricardo Boechat, jornalista, comentou em seu programa de rádio sobre episódios recentes na política nacional, afirmando que o Senador Federal Roberto Requião tinha "cheiro de mau caráter", que era "corrupto", "violento", "uma figura abjeta, que nem o resto de sua família" e que "parecia dos irmãos metralha" em três dias diferentes.

Boechat foi condenado à pena de 1 mês e 16 dias de detenção pela prática do crime de injúria, convertida em restritiva de direitos, qual seja, prestação de serviços a comunidade pelo prazo de 3 meses $^{59}$. Em sede

57 MATSUURA, Lilian. Juca Kfouri não deve indenizar Ricardo Teixeira. Disponível em: 〈http://www.conjur.com.br/2010-jun-22/juca-kfouri-nao-indenizar-presidente-cbf-ricardo-teixeira〉. Acessado em 10 de setembro de 2015.

${ }^{58} \mathrm{Na}$ decisão monocrática do Ministro Relator Celso de Mello no Agravo de Instrumento no 675.276 do Supremo Tribunal Federal, foi declarado que "não se pode desconhecer que a liberdade de imprensa, enquanto projeção da liberdade de manifestação de pensamento e de comunicação, revestese de conteúdo abrangente, por compreender, dentre outras prerrogativas relevantes que lhe são inerentes, (a) o direito de informar, (b) o direito de buscar a informação, (c) o direito de opinar e (d) o direito de criticar."

59 Sentença que condena Ricardo Eugênio Boechat por crimes de calúnia, injúria e difamação. Disponível em: <http://www.robertorequiao.com.br/sentenca-que-condena-ricardo-eugenio-boechatpor-crimes-de-calunia-injuria-e-difamacao/>. Acessado em 15 de setembro de 2015.

Ricardo Boechat também foi condenado pelos crimes de calúnia e difamação na mesma ação penal. 
recursal $^{60}$, a $1^{\text {a }}$ Turma Criminal do Tribunal de Justiça de São Paulo decidiu por manter sua condenação, pois entendeu que:

"Esse é o perfil do recorrido, um conhecido jornalista que, diversamente do que se esperaria dele, lamentavelmente, exorbitou, e muito, o seu direito de livre manifestação de pensamento e enveredou para o campo do ilícito penal porque, dolosamente, violou a honra subjetiva (...) do recorrido, sem que houvesse qualquer justificativa para tanto e, por isso, deverá responder pelas práticas dos delitos apontados na queixa-crime.”

Assim, quando exposta a situação aos entrevistados, 80 pessoas concordaram que Ricardo Boechat havia praticado o delito de injúria, enquanto 20 pessoas entenderam que tal crime não havia se configurado. Entre as 80 pessoas que inferiram a tipificação da injúria, 42 atuam na área penal.

O quinto caso demonstrado era o do jornalista Diogo Mainardi, que, em sua coluna habitual que versava sobre política e jornalismo, havia escrito um artigo intitulado "A voz do PT", informando que Paulo Henrique Amorim, também jornalista, estava "na fase descendente da carreira", taxando-o de "censor".

O juiz de piso absolveu Mainardi das acusações, mas Amorim apelou e a decisão foi revertida pela $13^{\mathrm{a}}$ Câmara Criminal do Tribunal de Justiça de São Paulo, condenando o articulista a 1 mês de detenção e ao pagamento de 10 dias multa $^{61}$. A pena foi convertida para o pagamento de três salários mínimos. ${ }^{62}$

${ }^{60}$ Apelação $\mathrm{n}^{\mathrm{o}}$ 0017181-98.2011.8.26.0011 da $1^{\mathrm{a}}$ Turma Criminal do Tribunal de São Paulo: "O
recorrente alegou que, diversamente do que constou na r. sentença, as condutas imputadas a ele seriam
atípicas porque desprovidas do elemento subjetivo do tipo, que seria essencial para o processo de
adequação típica. Nesse sentido, o recorrente disse que, na condição de jornalista, apenas exerceu a sua
liberdade da expressão, amparada pela Constituição Federal e o seu direito à critica à postura
truculenta do recorrido em face do seu colega de profissão e à conduta dele no exercício do mandato
parlamentar, sem que adviesse qualquer ilícito penal." Em relação ao crime de difamação, a
Desembargadora Relatora Juliana Guelfi reduziu os dias multa, que antes foram fixados a seu máximo
legal, para 2,5 salários mínimos, ou seja, metade do valor anterior. <http://esaj.tjsp.jus.br/cjsg/getArquivo.do?cdAcordao=3219800\&cdForo=0\&vlCaptcha=tJaar $>$. Acessado em 09 de setembro de 2015. Diogo Mainardi também foi condenado pelo crime de difamação em concurso formal com o crime de injúria, totalizando a pena em 3 meses e 15 dias de detenção e ao pagamento de 11 dias multa. 
Das 100 pessoas entrevistadas no questionário aqui debatido, 93 disseram que entendiam não haver a tipificação do crime de injúria, enquanto 7 discordaram. Dos 7 entrevistados, três trabalham na área criminal.

Por fim, no sexto e último caso, foi exposto aos entrevistados o conflito entre o jornalista José Cristian Góes e o desembargador Edson Ulisses de Melo. Góes escreveu em seu blog um texto ficcional sobre o coronelismo, ${ }^{63} \mathrm{em}$ que não são citadas pessoas, ambientes, nem datas ${ }^{64}$. Edson se sentiu ofendido porque entendeu que estava sendo retratado no texto diante da expressão "jagunço de leis" utilizada por Cristian. ${ }^{65}$

O jornalista, então, foi condenado pelo Juizado Especial Criminal de Aracaju a uma pena de 7 meses de 16 dias de detenção, convertida em prestação de serviço à comunidade pelo mesmo período de tempo. Mesmo com a interposição de recurso de apelação, a Turma Recursal do Estado de Sergipe decidiu por manter a condenação nos termos da sentença do juiz de primeira instância ${ }^{66}$.

Quando perguntado aos entrevistados, 97 pessoas disseram não ter se configurado o crime de injúria, enquanto três disseram o contrário - e, das três que compreenderam a existência do delito, duas atuam na seara criminal.

\footnotetext{
${ }^{62}$ No HC n ${ }^{\circ}$ 103258/SP, o Ministro Relator Dias Toffoli decidiu pela prescrição da pretensão punitiva do Estado em relação à pena imposta a Diogo Mainardi.

${ }^{63}$ GÓES, Cristian. Eu, o coronel em mim. Disponível em: $\langle$ http://www.infonet.com.br/josecristiangoes/ler.asp?id=128810 $>$. Acessado em 11 de setembro de 2015.

64 "O texto é uma espécie de confissão de um homem da época do coronelismo brasileiro e que ainda hoje tem poder, mas não cita nomes de pessoas, cargos, lugares nem datas". Caso Góes chega ao Supremo. Disponível em: 〈http://artigo19.org/blog/caso-goes-chega-ao-supremo/>. Acessado em 11 de setembro de 2015.

Liberdade de expressão em pauta no STF: o caso Cristian Góes. Disponível em: <http://www.cartacapital.com.br/blogs/intervozes/liberdade-de-expressao-em-pauta-no-stf-o-casocristian-goes-6133.html>. Acessado em 11 de setembro de 2015.

65 "Ô povo ignorante! Dia desses fui contrariado porque alguns fizeram greve e invadiram uma parte da cozinha de uma das Casas Grande. Dizem que greve faz parte da democracia e eu teria que aceitar. Aceitar coisa nenhuma. Chamei um jagunço das leis, não por coincidência marido de minha irmã, e dei um pé na bunda desse povo."

${ }^{66}$ A Reclamação no 19775 , em trâmite no Supremo Tribunal Federal e de relatoria do Ministro Luiz Fux, foi ajuizada por José Cristian Góes para discutir se houve ofensa à autoridade da decisão proferida por tal Corte nos autos da ADPF 130.
} 
Diante da análise exposta pelos casos apresentados no questionário, percebe-se que, apesar de haver soluções visíveis e mais fáceis para determinadas situações, outras carregam certa subjetividade ou, então, estão numa penumbra normativa/doutrinária, o que pode explicar o fato de haver um número comparativo muito próximo entre os que acreditavam ter se configurado o crime de injúria ou não em alguns conflitos.

Nos embates entre Edmundo vs. Revista Veja, entre Diogo Mainardi vs. Paulo Henrique Amorim e entre Edson Ulisses de Melo vs. José Cristian Góes, somente no primeiro exemplo a opinião quase que unânime dos entrevistados coincidiu com a resolução jurídica do Tribunal, que decidiu pela absolvição da Revista Veja.

O mesmo não ocorreu nos dois outros casos. Apesar de a primeira instância do caso e $93 \%$ dos entrevistados entenderem que Diogo Mainardi não havia praticado o crime de injúria, ele foi condenado pelo Tribunal de Justiça de São Paulo. Cristian Góes, por sua vez, teve sua condenação mantida pelo Turma Recursal do Estado de Sergipe, ao passo em que 97\% das pessoas que responderam ao questionário entenderam não haver se configurado o delito.

Algumas possíveis justificativas para representar a polarização do entendimento dos entrevistados nos conflitos apresentados quanto ao fato de a maioria acreditar não ter havido a configuração do crime de injúria, é a sutileza da manifestação da opinião, a dúvida se foi efetivamente proferida uma ofensa e a fragilidade dos requisitos penais para a subsistência do crime.

Em contrapartida, nos casos de Merval Pereira vs. Paulo Henrique Amorim e de Ricardo Teixeira vs. Juca Kfouri, a porcentagem entre as pessoas que consideravam e que não consideravam a manifestação de opinião ser ofensiva e, portanto, crime, foi muito próxima, vez que no primeiro caso foi $66 \%$ e $34 \%$ e no segundo caso $51 \%$ e $49 \%$, respectivamente.

Assim, um cenário plausível para a contiguidade da porcentagem de opiniões acerca da tipificação ou não do crime de injúria nos casos acima é a 
característica subjetiva e dúbia do tipo penal da injúria. Isso ocorre porque a aferição da existência do animus é condição essencial para a existência do delito e, no entanto, a avaliação da possível intenção do autor do fato em injuriar uma pessoa é frágil - afinal, a não ser em casos veementemente claros, a única pessoa que de fato pode afirmar se houve intenção em ofender a dignidade ou o decoro é o próprio autor do fato.

Por fim, pode-se classificar o conflito de Roberto Requião vs. Ricardo Boechat como o mais forte e intenso ao se comparar a linguagem utilizada neste embate com os demais casos apresentados, bem como a quantidade de vezes em que o jornalista se referiu a Requião da maneira considerada ofensiva. Apesar de Boechat ter sido condenado pelo crime de injúria e a maioria dos entrevistados ter sustentado que ele incidiu no delito previsto no artigo 140 do Código Penal, fato é que $20 \%$ das pessoas que responderam o questionário inferiram que a conduta era atípica - valor que corresponde a 1/5 do total de entrevistados.

Isso indica que, mesmo no único caso com o maior número de pessoas afirmando a ocorrência da injúria, um grupo relativamente grande discordou desse entendimento, o que demonstra que a compreensão da matéria não é, de fato, consolidada.

Nas diretrizes de um Estado de Intervenção Mínima e sob as bases dos princípios gerais do Direito Penal, pode-se dizer que, de certa forma, é temerário criminalizar a manifestação de pensamento com o crime de injúria, que é de menor potencial ofensivo, formal e depende da constatação do animus, tendo em vista a subjetividade do que é ou não considerado como ofensa e, assim, crime.

Analisando o resultado do questionário, percebe-se que, nos casos de Merval Pereira vs. Paulo Henrique Amorim, de Juca Kfouri vs. Ricardo Teixeira e de Roberto Requião vs. Ricardo Boechat, os entrevistados efetivamente se dividiram de maneira em que tanto o grupo que afirmou haver 
a configuração do delito quanto o grupo que entendeu pela atipicidade do crime de injúria quedaram com um número considerável de pessoas. Ou seja, as respostas foram quase que diametralmente opostas em alguns dos enunciados apresentados às pessoas, havendo resultados próximos a $50 \%$ dos dois lados.

Inclusive, em alguns casos, a maioria dos entrevistados divergiu da decisão real dada pelo Tribunal no caso concreto, como aconteceu nos conflitos entre Juca Kfouri vs. Ricardo Teixeira, entre Diogo Mainardi vs. Paulo Henrique Amorim e entre Cristian Góes vs. Edson Ulisses de Melo.

Através dos dados coletados pela pesquisa, é concebível pensar que o preço a se pagar pela criminalização da manifestação de pensamento é alto, haja vista as dúvidas e subjetividades que permeiam o tipo penal da injúria.

Assim, eventualmente, pessoas podem ser condenadas em situações nas quais não havia animus injuriandi e as diferentes instâncias podem reformar decisões por entenderem que há ou não a configuração do crime, utilizando argumentos contrários de mesmo peso normativo para provar um ponto oposto. Uma consequência disso é a insegurança jurídica, algo arriscado de ocorrer em uma matéria como a penal, que gera constrangimentos e o próprio processo pode se equivaler ao efetivo cumprimento da pena ${ }^{67}$.

\subsection{Divergência jurisprudencial}

Com o fim de exemplificar e aprofundar o estudo no que tange ao conflito entre honra e a liberdade de expressão no âmbito da seara criminal, foi

\footnotetext{
67 "(...) deve-se lembrar que a aplicação do princípio da intervenção mínima deve ser permanente, pois as medidas restritivas de direitos e liberdade, que são consequências da utilização do Direito Penal, deverão ser consideradas como ultima ratio, pois violam a integridade física e psíquica de todo ser humano que porventura venha a elas ser submetido". Voto da Desembargadora Relatora Elizabete Alves de Aguiar na apelação $\mathrm{n}^{\mathrm{o}}$ 0006906-81.2012.8.19.0001 da $8^{\mathrm{a}}$ Câmara Criminal do Tribunal de Justiça do Estado do Rio de Janeiro.
} 
realizada uma pesquisa de processos criminais nos sites do Tribunal de Justiça do Rio de Janeiro e do Tribunal de Justiça de São Paulo, utilizando-se a palavra chave "injúria", os quais tiveram seu julgamento em sede recursal dentro do ano de 2013, para analisar a justificativa dos magistrados ao condenar ou absolver um indivíduo acusado de perpetrar o crime de injúria, seja mantendo ou reformando as decisões de primeira instância. Para tanto, foram escolhidos 8 (oito) acórdãos de tais tribunais: 4 (quatro) que condenam e 4 (quatro) que absolvem o acusado.

$O$ primeiro processo que entende pela condenação, uma apelação de $n^{\circ}$ 0087340-57.2012.8.19.0001 julgada perante a $1^{\mathrm{a}}$ Câmara Criminal do Tribunal de Justiça do Estado do Rio de Janeiro, versava sobre o fato de que a apelante, que, na época dos fatos, tinha 72 anos, havia "de forma livre e consciente" injuriado a apelada, sua vizinha e esposa de seu sobrinho, de "macumbeira, bunda seca que não serve nem para ter filho", pois viu uma construção na propriedade da apelada que parecia de uma obra para montar uma laje - o que a apelante não queria, já que iria tapar a frente de sua casa.

Tal manifestação não foi classificada como injúria qualificada (artigo 140, parágrafo $3^{\circ}$ do Código Penal), pois o Ministério Público entendeu que a vítima não se sentiu ofendida em sua religião, que é católica, e não candomblé.

A defesa da apelante requereu sua absolvição e "aduziu que o Direito Penal assume a posição de ultima ratio, ou seja, somente deve ser manejado quando outros ramos do Direito falharem". Pleiteou, portanto, para que fosse reconhecida a insignificância do ato quanto ao merecimento de tutela do direito penal e sugeriu que, no máximo, fosse reconhecida a atuação do direito civil nesse caso.

De todo modo, a $1^{\text {a }}$ Câmara Criminal, por unanimidade, entendeu por manter a condenação da apelante em um mês de detenção, substituída pela pena de prestação pecuniária no valor de um salário mínimo vigente à época, 
pois vislumbrou que havia animus injuriandi, justificando com o fato de que a vítima havia se sentido muito magoada, e que sabe-se:

"que o Direito Penal somente deve ser acionado quando os outros ramos do direito não conseguem responder o anseio social. Todavia, não podemos fechar os olhos para a legislação vigente, deixando de aplicá-la sem que haja fortes fundamentos. $\mathrm{O}$ fato de ser a apelante uma senhora idosa, com mais de 70 anos, não lhe dá o direito de fazer o que bem quer."

O segundo processo é um recurso em sentido estrito, de $\mathrm{n}^{\circ} 9000014-$ 60.2011.8.26.0577 da 8 Câmara de Direito Criminal do Tribunal de Justiça de São Paulo. O recorrido havia insultado a recorrente de "ladra" e "sem vergonha" durante a visita da recorrente à sua filha, que estava sob guarda provisória do recorrido, e o juízo de piso havia entendido pela ausência de justa causa, rejeitando a queixa crime.

A segunda instância, por sua vez, resolveu reformar tal decisão por visualizar que os "fatos tidos como criminosos" estavam "expostos de forma clara e objetiva", havendo "indícios de autoria e prova da materialidade" e, finalmente, determinou "com recomendação" o regular prosseguimento da ação penal, conforme o voto do Desembargador Relator.

$\mathrm{Na}$ apelação $\mathrm{n}^{\mathrm{o}}$ 0265570-58.2011.8.19.0001 julgada perante a $2^{\mathrm{a}}$ Turma Recursal Criminal do Tribunal de Justiça do Estado do Rio de Janeiro, terceiro exemplo elencado, foi mantida a sentença do juízo de piso por unanimidade. A apelante, proprietária do apartamento em que a apelada morava, foi condenada por ter chamado esta última de "cínica" e "mentirosa" durante uma vistoria, "ao constatar que faltava o botão de acionamento do ar condicionado da sala e que as chaves dos armários da cozinha também não estavam em seus lugares", porque interpretou-se que ditos qualificativos caracterizavam uma ofensa à honra.

A Relatora, por fim, declara que: 
"Nem se diga que a exaltação por si só seria suficiente para afastar o animus injuriandi, do contrário estaríamos dando uma 'carta branca' para os agressivos, 'esquentadinhos', 'mal educados, prepotentes ou 'malucos de plantão', apenas, porque serem explosivos. (...) Conclui, sim, ser a Ré uma pessoa que se apresenta agressiva e que precisa de limites para não ofender as outras gratuitamente. (...) Evidente o dolo direto."

Como quarto exemplo, há a apelação $\mathrm{n}^{0}$ 0000734-32.2004.8.26.0447, julgada pelo $1^{\circ}$ Grupo de Seção Criminal do Tribunal de Justiça do Estado de São Paulo.

O apelante foi condenado pela primeira instância pelo crime de injúria, pois publicou uma matéria no jornal "Tribuna Popular" chamando o apelado de "prefeito covarde" e "prefeitinho". Veiculou, também, uma "charge em que o mostrava com cruz suástica na manga da camisa, na saudação com o braço erguido, imitando gesto nazista, ao tempo que, no espelho onde se mirava, refletia-se figura semelhante a do ditador Adolf Hitler".

A segunda instância manteve o decreto condenatório do juiz de piso, relatando que:

"A liberdade de opinião deve ser assegurada, para que todos tenham direito à informação, sem os riscos de que o poder político possa interferir para cerceá-la. (...) Contudo, a liberdade de imprensa não é bilhete de indenidade que tudo permite e nada impõe limites. (...) Ainda quando aquela é criticada no exercício da atividade pública, não pode ser atingida de forma a serem violados tais direitos. Ninguém deve ser chamado de covarde e mostrado como partidário de ideias nazistas. Isso vai além do justo direito à crítica e o atingido tem motivos para dizer-se ofendido na honra."

Dos processos que entendem pela absolvição, o primeiro é uma apelação de $n^{0}$ 0000400-76.2012.8.26.0201 da $4^{\mathrm{a}}$ Câmara de Direito Criminal do Tribunal de Justiça de São Paulo. A apelante informa que as apeladas a chamaram de "biscate e vagabunda", que o baile dela "é uma zona" e ela "a chefe das quengas" por não ter deixado uma das apeladas entrar em sua festa.

A sentença do juízo de primeira instância absolveu as apeladas, decisão mantida pela Câmara. O relator ressalta que há divergência entre as versões da 
apelante e das apeladas, assim como elas já tinham problemas entre si em momento anterior aos fatos.

Por fim, declara que "não ficou configurado o dolo específico, exigido, neste caso, tratando-se, realmente, de discussão nervosa entre as partes, (...) sem controle e sem intenção específica de macular a honra".

A apelação criminal de $\mathrm{n}^{\mathrm{o}}$ 0024071-56.2008.8.19.0001, segundo exemplo, da $2^{\text {a }}$ Câmara Criminal do Tribunal de Justiça do Estado do Rio de Janeiro, restou por manter a sentença de absolvição do apelado, que, de acordo com a narrativa acusatória, havia escrito em seu blog que ocorreram "pilantragens" na venda de um imóvel intermediada pela empresa dos apelantes, havendo, também, um "falso construtor".

No entanto, a $2^{\mathrm{a}}$ Câmara entendeu que o blog do apelado tem como objetivo divulgar informações sobre compra de imóveis em geral, e não só comentar a aquisição do imóvel auxiliada pelos apelantes. Assim, não havia prova de dolo de injuriar suficiente nos autos, visualizando-se mais um "inconformismo e uma frustração" do que "a vontade deliberada de ofendêlos".

O Relator finalizou seu voto declarando que "vale lembrar o caráter subsidiário do Direito Penal, pelo que não pode ser ele invocado para compor todo e qualquer conflito existente no meio social".

O terceiro exemplo é o da apelação ${ }^{\mathrm{o}}$ 0000346-23.2011.8.19.0078 da $2^{\mathrm{a}}$ Turma Recursal Criminal do Tribunal de Justiça do Estado do Rio de Janeiro. O recorrente havia sido condenado pela primeira instância pela prática do crime de injúria por ter criticando a atuação parlamentar do recorrido quanto à resistência da adesão do Município a um programa do Governo Federal, ao escrever num jornal: "sabemos que ele é muito moço e que não teve tempo de estudar a fundo a legislação".

A $2^{\mathrm{a}}$ Turma, por sua vez, decidiu por reformar a sentença e absolvê-lo, afirmando que: 
“O ânimo de injuriar não se confunde com o exercício do direito de crítica, corolário da liberdade de manifestação do pensamento assegurada constitucionalmente. Não se reconhece, portanto, no atuar (...) o elemento subjetivo do crime de injúria, vez que não intentava denegrir a reputação do Querelante. Em se tratando de parlamentar, o Querelante está sujeito à críticas inerentes à atuação pública”.

O quarto e último exemplo é o da apelação $\mathrm{n}^{0}$ 012981781.2001.8.19.0001 da $8^{\text {a }}$ Câmara Criminal do Tribunal de Justiça do Estado do Rio de Janeiro, na qual o apelante pleiteava pela reforma da sentença, pois o apelado teria praticado o crime de injúria ao chamá-lo de "ladrão" e "corrupto" dentro de um ônibus, quando os dois aguardavam para descer do veículo e iniciaram uma discussão. Ambos tinham um histórico de brigas e discórdias.

Em seu voto, o Desembargador Relator Valmir dos Santos Ribeiro diz, em relação ao crime de injúria:

(...) ante a manifesta ausência do elemento subjetivo do delito, posto que igualmente fruto de acirrada discussão entre querelante e querelado, não se sabendo determinar, sequer, quem a tenha efetivamente provocado, haja visto que, quando da aproximação policial, ambos já se encontravam trocando insultos.

Manteve-se, assim, a sentença recorrida e o apelado permaneceu absolvido.

Vislumbra-se que, através da jurisprudência apresentada, soluções contrárias baseadas em argumentos opostos, com o mesmo peso hierárquico e normativo, foram dadas em conflitos semelhantes.

Isso ocorreu, por exemplo, no terceiro processo que condena e no primeiro e quarto processos dos que absolveram. Enquanto o decreto condenatório do terceiro processo se baseia no entendimento de que o calor da discussão não é suficiente para descaracterizar o animus injuriandi, no primeiro e no quarto processos nos quais os réus foram absolvidos os magistrados entenderam de forma contrária, dizendo que não se configurou o dolo específico diante da existência de discussão por não haver intenção específica em macular a honra. 
Outra contrariedade em relação à compreensão dos propósitos do Direito Penal pode ser apontada quando se comparam as ofensas proferidas no segundo processo dos que absolveram com o primeiro e o segundo dos que condenaram. No processo que absolve, o julgador invocou o caráter subsidiário do ramo criminal e que este não deveria solucionar todos os conflitos que permeiam a sociedade, concebendo que do conflito se extraía mais um inconformismo e frustração do que vontade de ofender. Nos processos que condenam, por sua vez, o entendimento foi diverso. Foi dito que, apesar de o Direito Penal ser de ultima ratio, "não podemos fechar os olhos para a legislação vigente, deixando de aplicá-la sem que haja fortes fundamentos", havendo, inclusive, recomendação para o prosseguimento da ação penal diante dos indícios de autoria e materialidade.

Por fim, no que tange o conflito da liberdade de expressão com o direito à honra envolvendo políticos, o exemplo do terceiro processo que absolveu e o quarto processo que condenou demonstraram opiniões antagônicas em relação a qual direito deveria prevalecer. Enquanto a primeira hipótese entende que o animus injuriandi não pode ser confundido com o animus criticandi, devendo prevalecer, assim, a liberdade de manifestação de pensamento, a segunda hipótese considerou que, mesmo que a liberdade de opinião deva ser assegurada, ela tem de ter limites para não ultrapassar o direito à crítica.

Como pode-se depreender das comparações realizadas, não há entendimento pacífico quanto à incidência do crime de injúria. Mesmo que a configuração do crime de injúria dependa da interpretação do contexto dos fatos e da intenção em ofender, como não há um entendimento concreto e constante, casos similares nem sempre têm decisões parecidas. As resoluções de embates jurídicos, portanto, podem variar de magistrado para magistrado, configurando um "decisionismo" judicial. 


\subsection{Doutrina versus a "vida como ela é"}

Para se entender melhor a ocorrência de casos de injúria, é preciso, primeiramente, que a doutrina faça bem o seu papel de identificar as condições teóricas relevantes para a tipificação de uma conduta criminosa de maneira satisfatória, para que a aplicação prática da mesma seja correspondente. Afinal, além de legislação e da jurisprudência, é através dos conceitos provenientes da doutrina penalista que os operadores do direito irão basear, justificar e motivar suas decisões.

É um exercício de causalidade básico: quando a doutrina exerce a sua função didática e teórica, consequentemente os juízes e tribunais produzem resultados práticos menos suscetíveis a erros de interpretação e aplicação, ou não, do direito quanto à possível tipicidade de condutas em casos de zonas cinzentas.

Por isso, para que os embates penais tenham a solução mais cabível e justa dentro de suas peculiaridades, é necessário que as definições dos crimes, suas elementares sejam consolidadas e constantes, para que haja segurança jurídica. Casos similares, portanto, deveriam ter resoluções e embasamentos parecidos.

Num cenário como o nosso, no qual é comum a judicialização dos conflitos corriqueiros da vida para se chegar a uma solução, mesmo que jurídica, há de se ter cuidado com a banalização do direito em geral e, especialmente, o penal, que deve ser invocado tão somente em último caso. Junto a isso, não se pode esquecer que, ao menos no que envolve o crime de injúria, a circunstância do fato e identificação da intenção no momento em que foi proferida a ofensa são essenciais para a subsistência do delito, porém podem ser subjetivos. Isso ocorre porque a construção factual do suposto crime 
é contada a partir do campo de visão das partes, contaminado pela parcialidade e perspectiva de cada um ${ }^{68}$.

Assim, o que se pode avaliar diante do resultado da pesquisa realizada e da divergência jurisprudencial apontada é que há certa instabilidade no que é considerado ou não ofensa e, respectivamente, conduta típica ou atípica. Isso se dá porque, além do significado da própria palavra dirigida à suposta vítima, o animus e o contexto de ofender também são subjetivos para se aferir, mesmo sendo imprescindíveis para a configuração do crime de injúria.

Nesse sentido, os exemplos clássicos dados pela doutrina tradicional e moderna para ilustrar a ocorrência do crime de injúria podem não ser cabíveis na atualidade, na "vida como ela é". Parece, inclusive, pouco crível que as situações cotidianas sigam os exemplos que a doutrina prega, mesmo que em contextos diferentes.

Para os doutrinadores de Direito Penal, chamar alguém de "corno", “anta”, ignorante"69, "cachorro", "trouxa", "banana"70, "incapaz", "hipócrita" e "relapso",71, pode configurar, dependendo da situação ${ }^{72}$, injúria. Algumas

\footnotetext{
68 "Com razão Carnelutti quando dizia (já em 1925) ser estéril a discussão a respeito de viger a verdade real (material) ou a verdade processual (formal). O problema é a 'verdade'. Para o autor, inspirado em Heidegger, a verdade é inalcançável, até porque a verdade está no todo, não na parte; e o todo é demais para nós. Além de inalcançável, tampouco existem verdades absolutas, como a própria ciência encarregou-se de demonstrar, pois todo o saber é datado e tem prazo de validade (Einstein). (...) Não se nega a verdade, mas tampouco a idolatramos. (...) A verdade assim é contingencial e a legitimação da decisão se dá através da estrita observância do contraditório e das regras do devido processo. São essas regras que, estruturando o ritual judiciário, devem proteger do decisionismo e também do outro extremo, onde se situa o processo inquisitório e sua verdade real." LOPES JR., Aury. Direito processual penal. 11 ed. São Paulo, Saraiva, 2014. Pág. 584/591

${ }^{69}$ BITENCOURT, Cezar Roberto. Tratado de direito penal, 2: parte especial, dos crimes contra a pessoa. 11a ed. São Paulo: Saraiva, 2011. Págs. 308/309.

${ }^{70}$ HUNGRIA, Nelson. Comentários ao Código Pena, volume VI. $5^{\text {a }}$ ed. Rio de Janeiro: Forense, 1980. Págs. 91/92.

${ }_{71}^{71}$ JESUS, Damásio E. de. Código Penal anotado. 18a ed. atual. São Paulo: Saraiva, 2007. Pág. 498.

72 "Enfim, o contexto em que a injúria é cometida é fundamental para sua configuração, oportunidade em que se verificará o dolo do agente, ou seja, a finalidade que tem de ultrajar a honra subjetiva da vítima, ofendendo-lhe a dignidade ou o decoro, ou se, na verdade, busca dar sentido completamente diferente ao de uma agressão à honra daquela pessoa contra a qual são dirigidas as palavras ou atitudes aparentemente injuriosas". GRECO, Rogério. Curso de Direito Penal: parte especial, volume II: introdução à teoria geral da parte especial: crimes contra a pessoa. 10a ed. Niterói, Rio de Janeiro: Impetus, 2013. Pág. 467.
} 
palavras, inclusive, perdem sua conotação negativa e são ressignificadas no decorrer do tempo, virando positivas e vice-versa ${ }^{73}$.

Definir quando ocorre a prática do crime pode ser desafiador e perigoso para a seara penal, que é de ultima ratio $^{74}$, tutela bens essenciais para a existência humana e coíbe condutas com punições mais severas do que as demais áreas jurídicas.

Ter flexibilidade e fragilidade em um tipo penal, em especial de menor potencial ofensivo, como é o caso da injúria, é contraditório com as características próprias do ramo criminal. Se a didática trata de exemplos subjetivos e os operadores de direito se baseiam na doutrina para motivar e decidir conflitos jurídicos, é possível e provável que, por não haver definições e critérios consolidados, argumentos diferentes com o mesmo peso normativo possam ser usados para sustentar qualquer tese diante de uma situação - o que gera insegurança jurídica.

Em sua obra, Damásio de Jesus afirma, praticamente conduzindo uma inversão do ônus da prova, que:

“A expressão, por si só, é suficiente para retratar a intenção lesiva do agente, sendo difícil demonstrar a ausência da vontade de ofender. (...) Trata-se, entretanto, de uma presunção relativa, cabendo ao ofensor a tarefa de demonstrar não ter agido com o dolo próprio do crime." 75

É complicado enquadrar situações comuns do dia-a-dia no crime de injúria, principalmente quando se analisa a compatibilidade do tipo penal na

\footnotetext{
73 "É necessário redobrada cautela quando se trata de limitar a liberdade de expressão em razão do conteúdo das ideias manifestadas. É preciso evitar a todo custo que este direito fundamental tão importante para a vitalidade da democracia e para a auto-realização individual torne-se refém das doutrinas morais majoritárias e das concepções sobe o "politicamente correto", vigentes em cada momento histórico."

SARMENTO, Daniel. Livres e Iguais: Estudos de Direito Constitucional. Rio de Janeiro: Editora Lumen Juris, 2006. Pág. 209.

74 "En resumen, las razones de Jakobs para realizar estas afirmaciones son las seguientes: en primer lugar, entiende acertadamente que el derecho penal no es el único método de control social". BERTONI, Eduardo Andrés. Libertad de Expresión en el Estado de Derecho. Buenos Aires: Del Puerto, 2007, $2^{\text {a }}$ edição. Pág. 42

${ }^{75}$ JESUS, Damásio E. de. Código Penal anotado. 18a ed. atual. São Paulo: Saraiva, 2007. Pág. 500.
} 
sociedade atual e a maneira como a doutrina o enxerga e explica, já que, dependendo do contexto, em uma briga de trânsito ou de condomínio ou até em discussões de futebol ou de política, ou seja, conflitos rotineiros, podem ocorrer - e ocorrem - injúrias. A maioria desses conflitos, contudo, não é levado ao conhecimento do sistema penal, integrando a cifra oculta ${ }^{76}$ no que tange ao crime de injúria.

Dessa forma, para haver maior coerência com a atualidade e ter normas que reflitam embates jurídicos relevantes, é importante que a legislação e a doutrina acompanhem o desenvolvimento da sociedade, reavaliando, no caso penal, a necessidade ou não da tutela de bens jurídicos diante de certas situações.

Como se pretendeu demonstrar com a pesquisa realizada e com a análise de divergência da jurisprudência, a incidência do crime de injúria é imprecisa, pois depende da compreensão do aplicador do direito acerca dos fatos apresentados. Essa incerteza também aparece de maneira sutil na doutrina penal, que recai em exemplos antiquados e, às vezes, incompatíveis com os dias atuais.

Já que a existência do delito de injúria depende de contextualização, que é uma noção geralmente pessoal, pode-se dizer que a ocorrência desse crime pode se dar a qualquer momento, pois a leitura realizada para a aferição de sua existência depende sempre da interpretação que o julgador terá da situação imposta, tendo ou não $\mathrm{o}$ autor do fato a intenção em injuriar

\footnotetext{
76 "(...) a prática criminosa não ficaria limitada à pessoas efetivamente processadas e condenadas, tal como o senso jurídico exige. Era preciso fugir do perigo que é vincular o estudo do criminoso ao estudo dos selecionados pelo sistema, pois obviamente a prática criminosa existe mesmo quando o agente permanece fora das estatísticas oficiais." SUTHERLAND, Edwin H. Crime de colarinho branco: versão sem cortes. 1. ed. Rio de Janeiro: Revan, 2015. Pág. 15.
} 


\section{CAPÍTULO 4 - A NORMATIZAÇÃO DOS CRIMES CONTRA A HONRA}

Neste capítulo, será realizada uma comparação para apontar as mudanças normativas entre a disposição dos crimes contra a honra atualmente e o previsto pelo Projeto de Lei do Senado $n^{\circ} 236$, de 2012, também conhecido como o anteprojeto do novo Código Penal. Posteriormente, será exposto um panorama dos delitos contra a honra no âmbito da Organização dos Estados Americanos, como uma investida para se compreender melhor a tendência dos países que a integram quanto à criminalização dos crimes de opinião.

\subsection{O Código Penal brasileiro atual e o anteprojeto do novo Código Penal}

Os crimes contra a honra estão dispostos no Código Penal brasileiro (Decreto-Lei $\mathrm{n}^{\circ} 2.848$, de 7 de dezembro de 1940) entre os artigos 138 e 140, que prevêem, respectivamente, os crimes de calúnia, difamação e injúria.

O delito de calúnia se configura quando o autor do fato, com animus caluniandi (intenção em caluniar), imputa falsamente a prática de um fato conceituado como crime a uma pessoa. Assim, a ocorrência da calúnia depende dos seguintes requisitos: (i) deve-se imputar um fato; (ii) tal fato deve ser estabelecido como crime; e (iii) esse fato criminoso deve ser falso ${ }^{77}$. É possível, inclusive, caluniar os $\operatorname{mortos}^{78}$.

\footnotetext{
${ }^{77}$ De acordo com o artigo 138, § $3^{\circ}$ do Código Penal: "admite-se a prova da verdade, salvo: I - se, constituindo o fato imputado crime de ação privada, o ofendido não foi condenado por sentença irrecorrível; II - se o fato é imputado a qualquer das pessoas indicadas no nº I do art. 141; III - se do crime imputado, embora de ação pública, o ofendido foi absolvido por sentença irrecorrível."

${ }^{78}$ Artigo 138, § $2^{\circ}$ do Código Penal.
} 
A pena prevista para esse crime é de detenção de seis meses a dois anos cumulado com multa. A pessoa que divulga a falsa imputação do crime também incorre na mesma pena ${ }^{79}$.

Já a difamação ocorre quando fatos determinados são imputados a uma pessoa, com animus difamandi, objetivando macular sua honra objetiva (reputação), não importando sua veracidade, a não ser nos casos em que o ofendido é funcionário público e a ofensa proferida era relacionada ao seu ofício $^{80}$. A pena prevista para esse crime é de detenção de três meses a um ano e multa.

Por último, a injúria, como previamente demonstrado, ocorre quando o autor do fato imputa, com animus injuriandi, uma qualidade negativa à vítima, maculando sua honra subjetiva, ou seja, o conceito que a pessoa tem de si mesma. A punição para esse crime é de detenção de um a seis meses ou multa $^{81}$.

Caso a injúria envolva violência ou vias de fato, que tenham natureza aviltante, a pena passa a ser de detenção de três meses a um ano cumulado com multa, fora a pena do ato violento praticado $^{82}$. Se a ofensa proferida compreender "elementos referentes a raça, cor, etnia, religião, origem ou a condição de pessoa idosa ou portadora de deficiências" ${ }^{83}$, a pena passa a ser de reclusão de um a três anos, junto com o pagamento de multa.

Esse panorama normativo, no entanto, deve mudar, uma vez que o Projeto de Lei do Senado $n^{\circ}$ 236, de 2012, também conhecido como o novo Código Penal ${ }^{84}$, traz disposições diferentes quanto aos crimes contra a honra.

\footnotetext{
${ }^{79}$ Artigo 138, § $1^{\circ}$ do Código Penal.

${ }^{80}$ Artigo 138, parágrafo único do Código Penal.

${ }^{81}$ Conforme o artigo $140, \S 1^{\circ}$ do Código Penal, "o juiz pode deixar de aplicar a pena: I - quando o ofendido, de forma reprovável, provocou diretamente a injúria; II - no caso de retorsão imediata, que consista em outra injúria".

${ }^{82}$ Artigo $140, \S 2^{\circ}$ do Código Penal.

${ }^{83}$ Artigo 140, $\S 3^{\circ}$ do Código Penal.

${ }^{84}$ Disponível em: <http://www25.senado.leg.br/web/atividade/materias/-/materia/106404〉. Acessado em 07 de novembro de 2015.
} 


\title{
O anteprojeto do novo Código Penal trouxe bastante controvérsia ao
}

\author{
mundo jurídico, sendo caracterizado, até, como bastante punitivista ${ }^{85}$. Miguel
} Reale Júnior, ex-Ministro da Justiça e professor de Direito Penal, pontuou que:

"É uma obscenidade, é gravíssimo. Erros da maior gravidade técnica e da maior gravidade com relação à criação dos tipos penais, de proporcionalidade. (...) Seria uma vergonha para a Ciência Jurídica Brasileira se saísse um código com erros tão profundos. Quando você acha que encontrou um absurdo, leia o artigo seguinte. O artigo 137 prevê que a pena para difamação vai de um a dois anos. Já o artigo 140 diz que se a difamação for causada por meio jornalístico, a pena é o dobro. A Lei de Imprensa, que foi declarada inconstitucional, e era considerada dura demais, previa que a pena para isso era de três meses!" 86

De acordo com o relatório final ${ }^{87}$, a pena para o crime de calúnia passará a ser de prisão ${ }^{88}$ de um a três anos, sendo que, anteriormente, era de detenção de seis meses a dois anos e multa, e a exceção da verdade só caberá na hipótese

\footnotetext{
${ }^{85}$ VASCONCELLOS, Marcos de. País corre risco de aprovar pior Código Penal da história, criticam especialistas. Disponível em: <http://www.conjur.com.br/2015-mai-13/senado-analisa-pior-codigopenal-historia-dizem-especialistas $>$. Acessado em 08 de novembro de 2015.

Projeto que institui o novo Código Penal volta à Comissão do Senado. Disponível em: <http://www.conjur.com.br/2015-mai-13/projeto-institui-codigo-penal-volta-comissao-senado $>$. Acessado em 08 de novembro de 2015.

${ }^{86}$ CANÁRIO, Pedro; VASCONCELlOS, Marcos de. "Novo Código Penal é obscenidade, não tem conserto". Disponível em: <http://www.conjur.com.br/2012-set-02/entrevista-miguel-reale-juniordecano-faculdade-direito-usp>. Acessado em 07 de novembro de 2015.

Para Reale, projeto do novo Código Penal 'pode se tornar vergonha internacional'. Disponível em: $<$ http://www12.senado.leg.br/noticias/materias/2013/02/28/para-reale-projeto-do-novo-codigo-penalpode-se-tornar-vergonha-internacional>. Acessado em 07 de novembro de 2015.

${ }^{87}$ O relatório final diz: "Há dignidade na proteção da honra das pessoas, seguindo os passos da Constituição Federal que o faz em três incisos do rol dos direitos e garantias fundamentais. Mantém-se, na presente proposta, a tradicional distinção entre a proteção da honra objetiva e subjetiva, objeto dos crimes de calúnia, difamação e injúria. Estende-se a esfera da licitude para, expressamente, nela incluir o direito à crítica jornalística. É oferecida tutela à atuação funcional dos servidores públicos, anteriormente objeto do crime de desacato, determinando-se a aplicação em dobro das penas dos crimes contra a honra, nestas condições". Disponível em:

$\langle$ http://www.senado.gov.br/atividade/materia/getPDF.asp?t=110444\&tp=1 $>$. Acessado em 06 de novembro de 2015.

88 "Fim da distinção entre reclusão e detenção. A novidade mais significativa, neste trecho, é unificação das penas privativas de liberdade em uma única forma: prisão. Entendeu a Comissão de Reforma que é artificial a distinção, hoje existente, entre detenção e reclusão, justificável tão somente no momento de fixação do regime inicial de cumprimento da pena. Além disso, reclusão e detenção não se diferenciam no cumprimento da pena, que ocorre no mesmo tipo de estabelecimento. A distinção importante, preservada e, em vários sentidos, prestigiada pela Comissão é a dos regimes de cumprimento de pena e, para tanto, não se mostra necessária a distinção entre reclusão e detenção". Disponível em: <http://www.senado.gov.br/atividade/materia/getPDF.asp?t=110444\&tp=1 >. Acessado em 06 de novembro de 2015.
} 
de a vítima ter sido efetivamente condenada pelo crime que lhe tenha sido imputado. Já que a pena máxima ultrapassa o valor de dois anos, o Juizado Especial Criminal não será mais competente para julgar esse crime, mas, sim, a vara criminal comum.

O delito de difamação, por sua vez, terá como pena a prisão de um a dois anos, tempo diferente da previsão legal anterior, que era de detenção de três meses a um ano, cumulado com multa. Foi, inclusive, acrescentado um parágrafo para punir a divulgação de "fato que sabe inverídico, capaz de abalar o conceito ou o crédito de pessoa jurídica" com pena de prisão de, também, um a dois anos e a exceção da verdade quanto a pessoa jurídica.

Já o crime de injúria será punível com prisão de seis meses a um ano, de acordo com o anteprojeto do novo Código Penal, enquanto, na lei atual, a punição é de detenção de uma seis meses ou multa.

Para se configurar a injúria qualificada, foram incluídas ao tipo penal as hipóteses de ofensas que contenham referências ao sexo, identidade ou opção sexual e condição física ou social, e a sua pena passou a ser de prisão, em vez de reclusão, não havendo mais a necessidade de pagamento de multa.

Em relação à injúria real, sua punição passará a ser de prisão de seis meses a um ano e seis meses, fora a pena relacionada à violência praticada, enquanto, anteriormente, era de detenção de três meses a um ano e multa, além da pena correspondente à violência.

Foi criado, também, um artigo para coibir a ofensa à honra ou memória de pessoa morta, com punição de prisão de três meses a um ano e, caso a ofensa consista em calúnia, a pena será de prisão de seis meses a dois anos ${ }^{89}$, bem como um que torna os crimes contra a honra praticados contra a Justiça Eleitoral e os candidatos como crimes eleitorais ${ }^{90}$.

\footnotetext{
${ }^{89}$ Artigo 139 do anteprojeto do novo Código Penal.

${ }^{90}$ Artigo 325 do anteprojeto do novo Código Penal.
} 
Quanto às disposições comuns dos crimes contra a honra, a majoração da pena é de aumento de até o dobro, enquanto, antes, era de um terço. Foi acrescentado as hipóteses de aumento de pena quando a ofensa é cometida por meio jornalístico ou qualquer outro meio de comunicação que facilite sua propagação, bem como por servidor público que viole o sigilo de informação que deva permanecer em segredo, e retirado as situações de ofensas proferidas ao Presidente da República e a chefe de governo estrangeiro e a pessoa maior de 60 anos ou portadora de deficiência.

Com a majoração em dobro da pena dos crimes contra a honra, um jornalista, por exemplo, pode ser condenado em até 6 (seis) anos de prisão por calúnia publicada em jornal e, caso não seja reincidente, poderá ter como regime inicial de cumprimento de pena o semi-aberto, de acordo com o artigo $33, \S 2^{\circ}, b$ do Código Penal.

No cenário de exclusão de ilicitude, foram inseridas (i) a calúnia proferida em juízo durante a discussão da causa pela parte ou por seu procurador, (ii) a opinião desfavorável da crítica jornalística e (iii) a hipótese de relato ou "divulgação de fato atinente ao interesse público, que não seja acobertado por sigilo funcional, em razão do cargo, legal ou juridicamente assegurado" ${ }^{91}$ como condutas atípicas.

Por fim, o instituto da retratação, que antes abrangia tão somente a calúnia e a difamação com a anuência da vítima para extinguir a punibilidade do acusado, passará a incluir o caso da injúria.

\subsection{Os crimes contra a honra no âmbito da Organização dos Estados Americanos}

No cenário atual, a maioria dos 35 países que compõem a Organização dos Estados Americanos criminaliza os delitos de opinião. Através do exame

\footnotetext{
${ }^{91}$ Artigo 141, IV do anteprojeto do novo Código Penal.
} 
de Códigos Penais e jornais locais, analisou-se que ao menos seis países optaram por políticas de descriminalização ou não adotaram a seara penal como meio de solução de conflitos quanto a essas infrações, cabendo ainda uma investigação mais apurada em relação aos demais.

Pode-se dizer que o movimento de descriminalização dos crimes contra a honra, na América Latina, foi iniciado no México, no Uruguai e na Argentina. Esse vanguardismo teve o potencial de influenciar outras nações a seguirem pelo mesmo caminho, como Costa Rica ${ }^{92}$, El Salvador e Jamaica ${ }^{93}$.

Dito movimento não teve curso tranquilo no México. Composto por 31 Estados e um Distrito Federal, o México apresenta, em relação ao programa de descriminalização dos delitos contra a honra, dificuldades de homogeneizar um mesmo entendimento em caráter nacional. Diversos de seus Estados resistiram em alinharem-se com a postura política do Governo Federal de despenalizar ${ }^{94}$ os crimes de injúria, calúnia e difamação. Atualmente, mais da metade dos 31 Estados mexicanos penalizam os crimes contra a honra.

Foi no governo de Felipe Calderón que iniciou-se o processo de descriminalização dos delitos contra a honra. Na mesma toada, foram

${ }^{92}$ Costa Rica eliminates prison for defamation. Disponível em: < https://cpj.org/2010/02/costa-ricaeliminates-prison-terms-for-defamation.php>. Acessado em 05 de novembro de 2015.

${ }_{93}$ Jamaica fully abolishes criminal defamation, na unprecedented legislative action in the Caribbean. Disponível em: <https://knightcenter.utexas.edu/blog/00-14750-jamaica-fully-abolishes-criminaldefamation-unprecedented-legislative-action-caribbean>. Acessado em 05 de novembro de 2015.

${ }^{94}$ Preliminarmente, é necessário informar a conotação dada ao conceito de despenalização no presente trabalho. A autora adotou, para esse fim, a interpretação colacionada pelo ilustre Ministro Sepúlveda Pertence ao RE 430207 QO/RJ, de sua relatoria, pela qual o que caracteriza a despenalização é a eliminação de penas privativas de liberdade como medida repressiva - seja na forma principal ou substitutiva - da infração penal. Nesse mesmo sentido, a Corte Interamericana de Direitos Humanos caracteriza a descriminalização através da substituição da pena privativa de liberdade pelo pagamento de multa pecuniária. Ambos os casos - supressão do cumprimento de pena por meio do encarceramento ou instituição de multa como medida punitiva - representarão o conceito de despenalização e descriminalização.

"Considerou-se que a conduta antes descrita neste artigo continua sendo crime sob a égide da lei nova, tendo ocorrido, isto sim, uma despenalização, cuja característica marcante seria a exclusão de penas privativas de liberdade como sanção principal ou substitutiva da infração penal". Posse de droga para uso pessoal é crime, logo, incide falta grave. Disponível em: <http://lfg.jusbrasil.com.br/noticias/1356373/posse-de-droga-para-uso-pessoal-ecrime-logo-incide-falta-grave >. Acessado em 06 de novembro de 2015. 
revogados os artigos $1^{\circ}$ a 31 da Lei de Delitos de Imprensa, numa clara demonstração de que a liberdade de expressão estava, então, sendo prestigiada como nunca havia sido no México. Esse prestígio foi fortalecido pela "Declaração de Puebla", redigida em agosto de 2011 pelo Fórum Regional Federal da SIP (Sociedade Interamericana de Imprensa), que apontou os malefícios decorrentes da violação à liberdade de expressão, por travar o fluxo de informações.

Um exemplo emblemático que firmou o entendimento a favor da liberdade de expressão no México foi o processo do jornal La Jornada contra a revista Letras Libres, que acusou aquele último de ser cúmplice do grupo terrorista ETA. Sentindo-se atingido em sua honra, o La Jornada processou a revista, perdendo a causa 7 anos depois. A Primeira Sala da Suprema Corte de Justicia de la Nación do Mexico entendeu que a liberdade de expressão deveria prevalecer, criando um precedente importante ${ }^{95}$.

Em 2009, o Uruguai editou uma lei que despenalizou os crimes de injúria e difamação, desde que as informações relacionadas sejam de interesse público ou envolvam pessoas públicas e de relevância social. A lei também revogou o crime de desacato se direcionado a funcionário público. Adicionalmente, a lei ainda estabeleceu que a condenação por prática de crime contra a honra deveria ser alicerçada em prova de "real malícia", doutrina criada pela Suprema Corte dos Estados Unidos quando do julgamento do caso The New York Times $v$. Sullivan ${ }^{96}$. Por essa doutrina, deve ser determinado se a

\footnotetext{
95 Disponível em: <http://www.libertad-expresion.org.mx/noticias/la-jornada-vs-letras-libres/>. Acessado em 06 de novembro de 2015.

96“In New York Times v. Sullivan, supra, the United States Supreme Court ruled that the existing common law of defamation violated the guarantee of free speech under the First Amendment of the Constitution. It held that the citizen's right to criticize government officials is of such tremendous importance in a democratic society that it can only be accommodated through the tolerance of speech which may eventually be determined to contain falsehoods. The solution adopted was to do away with the common law presumptions of falsity and malice and place the onus on the plaintiff to prove that, at the time the defamatory statements were made, the defendant either knew them to be false or was reckless as to whether they were or not." Disponível em:

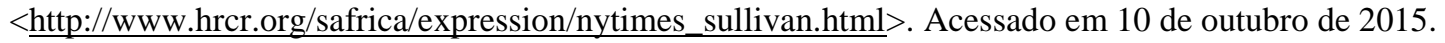


conduta do autor do fato, alegadamente criminosa, tratou-se de inegável negligência ou mentira proposital ${ }^{97}$.

A lei uruguaia refletiu o pensamento do futuro presidente uruguaio, José Mujica, para quem "a imprensa é um mal absolutamente necessário e imprescindível" e que "a melhor lei de imprensa é a que não existe"

No mesmo ano em que o Uruguai firmou seu posicionamento contra o cerceamento da liberdade de expressão, a Argentina promulgou a lei que extirpou do seu Código Penal os delitos de calúnia e injúria ${ }^{99}$. O alinhamento com o Uruguai se refletiu na adoção da figura da "real malícia" para condenações em processos de crimes contra a honra.

Pouco antes da lei que descriminalizou a injúria e a calúnia, a Argentina produziu um caso importante para o tema. O autor do livro "O Massacre de São Patrício", Eduardo Kimel, foi condenado criminalmente por ter citado um juiz argentino (Guillermo Rivarola) no caso do assassinato de três padres e dois seminaristas durante o regime militar argentino, ao criticar a lentidão da justiça no caso $^{100}$. Essa condenação foi duramente criticada pela Corte Interamericana de Direitos Humanos, que sentenciou a Argentina por violação aos direitos do escritor. A referida Corte determinou que a Argentina deveria "realizar um ato público de reconhecimento de sua responsabilidade dentro dos seis meses a partir da notificação da sentença" ${ }^{101}$.

\footnotetext{
${ }^{97}$ Disponível em: <http://es.rsf.org/uruguay-la-despenalizacion-de-los-delitos-09-072009,33395.html>. Acessado em 09 de outubro de 2015.

98 Mujica: "A la prensa no hay que andar toqueteándola". Disponível em: <http://www.lanacion.com.ar/1317526-mujica-a-la-prensa-no-hay-que-andar-toqueteandola>. Acessado em 07 de novembro de 2015.

${ }_{99}$ No más calumnias e injurias. Disponível em: 〈http://www.diariojudicial.com/contenidos/2009/11/19/noticia_0006.html $>$. Acessado em 06 de novembro de 2015.

${ }^{100}$ Caso Kimel vs. Argentina, disponível em: Argentina, sentence de 2/05/2008. Disponível em: $<$ http://www.corteidh.or.cr/docs/casos/articulos/seriec_177_esp.pdf $>$. Acessado em 03 de novembro de 2015.

${ }^{101}$ Disponível em: <http://knightcenter.utexas.edu/archive/blog/?q=pt-br/node/450 >. Acessado em 03 de novembro de 2015.
} 
A liberdade de expressão e a desproporção da penalização dos chamados crimes contra a honra foram objeto de debates e estudos desenvolvidos por alguns países da OEA. Esses debates levaram a modificações nas legislações dos países envolvidos em tais discussões, entre eles El Salvador.

A Assembleia Legislativa salvadorenha aprovou, em 2011, com o apoio do presidente Maurício Funes, um decreto que substituiu as penas de prisão, nos casos de crimes contra a honra e de violação de privacidade, por multas., além de estabelecer o direito de réplica do ofendido ${ }^{102}$. Nos casos de crimes dessa natureza cometidos por jornalistas, a Assembleia incluiu no referido decreto que o direito à réplica deveria ser cumprido num prazo de 3 dias, através da publicação da resposta do ofendido, sem custos para esse último, além da pena de suspensão da atividade jornalística do ofensor, por um período entre 6 meses e dois anos, ao invés da aplicação de multa. Maurício Funes vetou essa parte do decreto, por não concordar com dita suspensão.

A exposição de motivos do então presidente Maurício Funes em relação à descriminalização dos crimes contra a honra baseava-se em quatro premissas: a um, de que não se pode criminalizar sem regular, de forma clara, como e quando ocorre a violação à honra; a dois, de que a subjetividade da injúria não permite a sua criminalização, considerando que qualquer palavra dentro de um contexto maior pode criar o sentimento de ofensa em alguém, ainda que sem qualquer intenção de quem a tenha proferido; a três, de que a penalização financeira do ofensor é indispensável; e a quatro, de que penalizar quem exerce o seu direito de expressar sua opinião é um retrocesso dos direitos

\footnotetext{
${ }^{102}$ Presidente de El Salvador apoia projeto de lei que despenaliza crimes contra a honra, mas com alterações. Disponível em: <https://knightcenter.utexas.edu/pt-br/blog/presidente-de-el-salvadorapoia-projeto-de-lei-que-despenaliza-crimes-contra-honra-mas-com-alte>. Acessado em 06 de novembro de 2015.
} 
fundamentais, posto que qualquer um está livre para fazê-lo se não tiver o propósito de criar danos à imagem ou à reputação de alguém ${ }^{103}$.

Os pontos levantados por Maurício Funes em relação ao decreto apresentado pela Assembleia Legislativa fizeram com que fosse reativada a Comissão $\mathrm{Ad} \mathrm{Hoc}{ }^{104}$, visando aos debates sobre o projeto de lei acerca dos direitos de retificação e resposta. Esses direitos viriam em adição à proposta de despenalização dos crimes contra a honra. Para esse fim, a Assembleia Legislativa, através de financiamento obtido com o BID - Banco Interamericano de Desenvolvimento - contratou o jornalista e advogado uruguaio Edison Lanza para prestar consultoria à Comissão Ad Hoc acerca do tema. Nas rodadas para discussão da questão, Lanza esclareceu à Comissão, entre outros pontos, que o Uruguai já contava, há 26 anos, com uma lei que garantia o direito de resposta ao ofendido, e que dito direito, apesar de insculpido na Constituição da República de El Salvador, não estava regulamentado, representando um vazio legal dessa prerrogativa constitucional $^{105}$.

Os estudos desenvolvidos acerca dos crimes contra a honra nos países da OEA, e o tratamento aplicado a referidos delitos, apontaram para que a maioria desses países ainda aposta na penalização como meio de reparação de discursos considerados ofensivos. Essa prática do uso da privação de liberdade como contraprestação punitiva aos crimes contra a honra poderia ser repensada e levada a um debate mais profundo, especialmente considerando o pequeno

\footnotetext{
103 Disponível em: <https://knightcenter.utexas.edu/pt-br/comment/reply/1698 >. Acessado em $06 \mathrm{de}$ novembro de 2015.

${ }^{104}$ Disponível em: <http://www.diariocolatino.com/es/20121105/opiniones/109465/Establecer-elderecho-de-respuesta.htm>. Acessado em 05 de novembro de 2015.

${ }^{105}$ Em relação ao Brasil, a Câmara dos Deputados aprovou em outubro de 2015 as regras sobre o direito de resposta. O projeto, posteriormente, foi enviado ao Senado Federal para análise. Câmara aprova regras sobre direito de resposta; texto retorna para análise do Senado. Disponível em: <http://www2.camara.leg.br/camaranoticias/radio/materias/RADIOAGENCIA/498519-CAMARAAPROVA-REGRAS-SOBRE-DIREITO-DE-RESPOSTA-TEXTO-RETORNA-PARA-ANALISEDO-SENADO.html>. Acessado em 04 de novembro de 2015.
} 
potencial ofensivo que ditos delitos representam, aliado à necessária aplicação do Princípio da Intervenção Mínima.

A pesquisa elaborada sobre a situação legal dos países da Organização dos Estados Americanos em relação aos crimes contra a honra aponta para que há uma real resistência dessas nações à descriminalização desses delitos. Entre esses países encontra-se inserido o Brasil ${ }^{106}$, que ainda mantém-se na posição de conservar em seu sistema penal a punição dessa que é considerada uma conduta de menor caráter delitivo.

\footnotetext{
106 Que, por exemplo, já teve determinado pela Corte Interamericana de Direitos Humanos, em seis decisões diferentes, que se descriminalizasse os crimes contra a honra contra funcionários públicos por violar tratados internacionais sobre a liberdade de expressão. Brasil é denunciado por punir críticas a políticos. Disponível em: <http://politica.estadao.com.br/noticias/eleicoes,brasil-e-denunciado-porpunir-criticas-a-politicos-imp-,1091279) > Acessado em 08 de novembro de 2015.
} 


\section{CONCLUSÃO}

A proposta do presente trabalho não foi a de necessariamente fornecer soluções concretas quanto aos conflitos de opinião tratados em âmbito penal, mas de testar as premissas e questionar os paradigmas atuais que permeiam a criminalização do delito de injúria.

Com efeito, é incontestável que tanto a liberdade de expressão, quanto os direitos da personalidade e, em especial, o direito à honra, são essenciais para o bom funcionamento de uma sociedade dita democrática. Em muitos casos pode ser claro qual direito deve prevalecer em detrimento de outro. Porém, em circunstâncias fronteiriças, nas quais é cabível defender qualquer um dos direitos através de normas de mesma hierarquia, a tarefa de refletir sobre a prevalência entre a liberdade de expressão e o direito à honra é, no mínimo, árdua.

A liberdade de expressão é um direito recente, adquirido à custa de muita dor. Por mais valorados que sejam os direitos à honra e à dignidade, é fundamental reconhecer a fragilidade do direito à livre expressão e as consequências em tentar impor a mais radical das punições existentes no sistema jurídico para intimidar o discurso livre.

Diante de uma sociedade na qual é comum a judicialização de desavenças, a utilização da seara penal para coibir a injúria pode ser caracterizada como desproporcional frente ao potencial ofensivo de tal crime, somado aos princípios enraizados no Direito Penal brasileiro, principalmente o da intervenção mínima e o da fragmentariedade.

Fato é que, no que concerne o crime de injúria simples, há pouco interesse estatal de perseguir eventual ação penal - por isso que esta última é privada, dependendo de iniciativa da vítima. Além disso, a pena de caráter criminal, que tem como fundamentos a prevenção e a repressão, nem sempre resulta numa pacificação social, pois muitas vezes não consegue solucionar o 
conflito, funcionando como mera coação. Nesse sentido, uma reparação cível por ocasional mácula à honra seria mais justa e eficaz para a vítima do que a imposição de uma punição penal, que não teria como restaurar o bem jurídico afetado.

A tendência dos Estados membros da Organização dos Estados Americanos tem sido a de resistir à descriminalização dos crimes contra a honra, apesar dos inúmeros pleitos da Corte Interamericana de Direitos Humanos e de diversas Organizações Não-Governamentais, desconsiderando seu menor potencial ofensivo e o princípio da intervenção mínima. O Brasil, um de seus Estados membros, está nesse grupo que não elimina esses crimes de seu sistema penal, permanecendo desalinhado da orientação que caberia a um país que assume posição de player internacional.

Como se pretendeu demonstrar através da pesquisa realizada, da análise de divergência jurisprudencial e da contraposição dos exemplos doutrinários com conflitos na realidade, a caracterização do crime de injúria é frágil e inconstante, variando conforme o entendimento do intérprete do fato - o que pode vir a acarretar insegurança jurídica. Afinal, como manifestado pela Suprema Corte americana no caso Planned Parenthood v. Casey, "a liberdade não encontra refúgio em uma jurisprudência de dúvida". 


\section{REFERÊNCIAS BIBLIOGRÁFICAS}

BARROSO, Luís Roberto. Colisão entre Liberdade de Expressão e Direitos da Personalidade. Critérios de Ponderação. Interpretação Constitucionalmente adequada do Código Civil e da Lei de Imprensa. Disponível em 〈http://www.migalhas.com.br/arquivo_artigo/art_03-10-01.html >. Acessado em: 29 de setembro de 2015.

BARROSO, Luís Roberto. Constituição da República Federativa do Brasil anotada. São Paulo: Saraiva, 1998.

BARROSO, Luís Roberto. Temas de direito constitucional. Rio de Janeiro: Renovar, 2001.

BATISTA, Nilo. Introdução crítica ao direito penal brasileiro. Rio de Janeiro: Revan, $11^{\text {a }}$ edição, março de 2007.

BERTONI, Eduardo Andrés. Libertad de Expresión en el Estado de Derecho. Buenos Aires: Del Puerto, 2007, $2^{\mathrm{a}}$ edição.

BITENCOURT, Cezar Roberto. Tratado de direito penal, 2: parte especial, dos crimes contra a pessoa. $11^{a}$ ed. São Paulo: Saraiva, 2011.

BITENCOURT, Cezar Roberto. Tratado de direito penal: parte geral, I. $17^{\mathrm{a}}$ ed. rev., ampl. e atual. de acordo com a Lei n. 12.550, de 2011. São Paulo: Saraiva, 2012.

BONAVIDES, Paulo. Curso de direito constitucional. São Paulo: Malheiros Editores, 2011.

DELMANTO, Celso [et al.]. Código penal comentado. 8a ed. rev., atual. e ampl. São Paulo: Saraiva, 2010. 
FARIA, Bento de. Código Penal brasileiro. Volume IV. $3^{\text {a }}$ ed. atual. Rio de Janeiro: Distribuidora Record Editora, 1961.

FRAGOSO, Heleno Cláudio. Lições de direito penal: parte geral. 16 a ed. Rio de Janeiro: Forense, 2003.

GRECO, Rogério. Curso de Direito Penal: parte especial, volume II: introdução à teoria geral da parte especial: crimes contra a pessoa. $10^{\mathrm{a}}$ ed. Niterói, Rio de Janeiro: Impetus, 2013.

HUNGRIA, Nelson. Comentários ao Código Pena, volume VI. $5^{\text {a }}$ ed. Rio de Janeiro: Forense, 1980.

JESUS, Damásio E. de. Código Penal anotado. $18^{\mathrm{a}}$ ed. atual. São Paulo: Saraiva, 2007.

Leite, Fábio Carvalho. Liberdade de Expressão e Direito à Honra: novas diretrizes para um novo problema. In CLEVE, Clemerson Merlin, Freire Alexandre (Org.). Direitos Fundamentais e Jurisdição Constitucional. São Paulo: Ed. Revista dos Tribunais, 2014 (no prelo).

LEWIS, Antony. Liberdade para as ideias que odiamos: uma biografia da Primeira Emenda à Constituição americana. São Paulo: Aracati, 2011.

LOPES JR., Aury. Direito processual penal. 11 ed. São Paulo, Saraiva, 2014.

MARINONI, Luiz Guilherme. Aproximação crítica entre as jurisdições de civil law e de common law e a necessidade de respeito aos precedentes no Brasil. Revista da Faculdade de Direito - UFPR, Curitiba, n. 49, p. 11-58, 2009.

MENDES, Gilmar Ferreira. Curso de direito constitucional. $2^{\mathrm{a}}$. ed. rev. e atual. São Paulo: Saraiva, 2008. 
MIRABETE, Julio Frabbini e FABBRINI, Renato N. Manual de Direito Penal - Parte especial: arts. 121 a 234-B do CP. Volume II. $28^{\mathrm{a}}$ ed. rev. e atual. até 4 de janeiro de 2011. São Paulo: Atlas, 2011.

MORAES, Alexandre de. Direito constitucional. $7^{\mathrm{a}}$ ed. revista, ampliada e atualizada com a EC nº 24/99. São Paulo: Atlas, 2000.

NHUCH, Flavia Kamenetz. Liberdade de expressão e crimes contra a honra nos países da OEA. Disponível em: <http://www.pucrio.br/pibic/relatorio_resumo2013/relatorios_pdf/ccs/DIR/DIR-

Flavia\%20Kamenetz\%20Nhuch.pdf>. Acessado em: 04 de junho de 2015.

NOGUEIRA, Paulo Lúcio. Em defesa da honra. São Paulo: Saraiva, 1995.

NORONHA, E. Magalhães. Direito penal. São Paulo: Saraiva,1988-1991.

PELARIN, Evandro. Bem jurídico penal: um debate sobre a descriminalização. São Paulo: IBCCRIM, 2002.

PRADO, Luiz Regis. Comentários ao Código Penal: doutrina, jurisprudência selecionada, conexões lógicas com os vários ramos do direito. $3^{\mathrm{a}}$ ed. reform., atual. e ampl. São Paulo: Editora Revista dos Tribunais, 2006.

PRADO, Luiz Regis. Curso de direito penal brasileiro, volume 1: parte geral, arts. $1^{\circ}$ a $120.3^{\text {a }}$ ed. rev., atual. e ampl. São Paulo: Editora Revista dos Tribunais, 2002.

PRADO, Luiz Regis. Curso de direito penal brasileiro, volume 2: parte especial, arts. 121 a 249. $7^{\text {a }}$ ed. rev. e ampl. São Paulo: Editora Revista dos Tribunais, 2008. 
QUARESMA, Regina; OLIVEIRA, Maria Lúcia de Paula [et al.]. Direito constitucional brasileiro: perspectivas e controvérsias contemporâneas. Rio de Janeiro: Forense, 2006.

SARMENTO, Daniel. Livres e iguais: estudos de Direito Constitucional. Rio de Janeiro: Editora Lumen Juris, 2006.

SCHREIBER, Anderson. Direitos da personalidade. 2. ed. São Paulo: Atlas, 2013.

SILVA, Alexandre Assunção é. Liberdade de expressão e crimes de opinião. São Paulo: Atlas, 2012.

SILVA, José Afonso da. Curso de direito constitucional positivo. São Paulo: Malheiros Editores, 2014.

STRUCHINER, Noel. Para falar de regras: o positivismo conceitual como cenário para uma investigação filosófica acerca dos casos difíceis do direito. Rio de Janeiro. 2005. Tese (Doutorado em Filosofia) - Departamento de Filosofia da PUC-Rio.

Superior Tribunal de Justiça, Recurso Especial n 270.730, Ministra Relatora Nancy Andrighi, Brasília, 2000.

Supremo Tribunal Federal, Agravo de Instrumento $\mathrm{n}^{\circ}$ 675.276, Ministro Relator Celso de Mello, Brasília, 2011.

Supremo Tribunal Federal, Habeas Corpus n ${ }^{\circ}$ 103258/SP, Ministro Relator Dias Toffoli, Brasília, 2011.

Supremo Tribunal Federal, Reclamação nº 19775, Ministro Relator Luiz Fux, Brasília, 2015. 
SUTHERLAND, Edwin H. Crime de colarinho branco: versão sem cortes. 1. ed. Rio de Janeiro: Revan, 2015.

TEPEDINO, Gustavo; MORAES, Barboza, Heloisa Helena; MORAES, Maria Celina Bodin de. Código Civil interpretado conforme a Constituição da República. Rio de Janeiro: Renovar, 2004.

VANEIGEM, Raoul. Nada é sagrado, tudo pode ser dito: reflexões sobre a liberdade de expressão. São Paulo: Parábola Editorial, 2004.

WELZEL, Hans. Direito Penal. Campinas: Romana, 2003.

ZAFFARONI, Eugenio Raul, BATISTA, Nilo, ALAGIA, Alejandro, SLOKAR, Alejandro. Direito Penal Brasileiro, vol. II: teoria do delito: introdução histórica e metodológica, ação e tipicidade. Rio de Janeiro: Revan, 2010.

ZAFFARONI, Eugenio Raul. Em busca das penas perdidas: a perda da legitimidade do sistema penal. $5^{\text {a }}$ ed. Rio de Janeiro: Revan, 2001.

ZAFFARONI, Eugenio Raul. Manual de direito penal brasileiro: parte geral. São Paulo: Editora Revista dos Tribunais, 1997.

$1^{\text {a }}$ Câmara Criminal do Tribunal de Justiça do Estado do Rio de Janeiro, proc. $\mathrm{n}^{\circ}$ 0087340-57.2012.8.19.0001, Desembargadora Relatora Maria Sandra Kayat Direito, Rio de Janeiro, 2013.

$1^{\circ}$ Grupo de Seção Criminal do Tribunal de Justiça do Estado do Rio de Janeiro, proc. $\mathrm{n}^{\mathrm{o}}$ 0000734-32.2004.8.26.0447, Desembargador Relator Figueiredo Gonçalves, 2007.

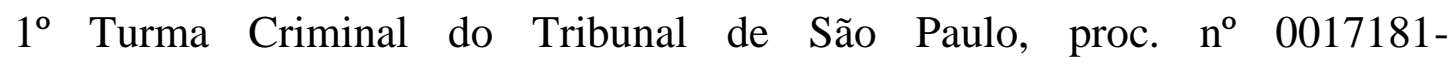
98.2011.8.26.0011, Desembargadora Relatora Juliana Guelfi, São Paulo, 2014. 
$2^{\mathrm{a}}$ Turma Recursal Criminal do Colégio Recursal de Santo André, proc. $\mathrm{n}^{\mathrm{o}}$ 0024348-59.2011.8.26.0564, Desembargador Relator José Wellington Bezerra da Costa Neto, São Paulo, 2011.

$2^{\text {a }}$ Turma Recursal Criminal do Tribunal de Justiça do Estado do Rio de Janeiro, proc. $\mathrm{n}^{\circ}$ 0265570-58.2011.8.19.0001, Desembargadora Relatora Claudia Marcia Gonçalves Dias, Rio de Janeiro, 2013.

$2^{\text {a }}$ Turma Recursal Criminal do Tribunal de Justiça do Estado do Rio de Janeiro, proc. $\mathrm{n}^{\circ}$ 0000346-23.2011.8.19.0078, Desembargador Relator Arthur Narciso de Oliveira Neto, Rio de Janeiro, 2013.

$2^{\circ}$ Juizado Especial Criminal de Itapuã, proc. no 0078766-45.2006.805.0001, Juíza Auristela Dias Ribeiro, Bahia, 2007.

$4^{a}$ Câmara de Direito Criminal do Tribunal de Justiça de São Paulo, proc. $n^{\circ}$ 0000400-76.2012.8.26.0201, Desembargador Relator Eduardo Braga, São Paulo, 2013

$8^{\text {a }}$ Câmara Criminal do Tribunal de Justiça do Estado do Rio de Janeiro, proc. $\mathrm{n}^{\mathrm{o}}$ 0006906-81.2012.8.19.0001, Desembargadora Relatora Elizabete Alves de Aguiar, Rio de Janeiro, 2012.

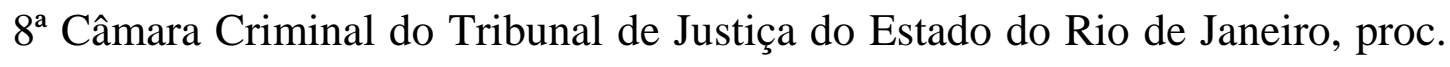
$\mathrm{n}^{\circ}$ 0129817-81.2001.8.19.0001, Desembargador Relator Valmir dos Santos Ribeiro, 2004.

$8^{a}$ Câmara de Direito Criminal do Tribunal de Justiça de São Paulo, proc. $n^{\circ}$ 9000014-60.2011.8.26.0577, Desembargador Relator Ivo de Almeida, São Paulo, 2013. 